\title{
Methane Gas Emissions: Methods of Improving the Efficiency of the Biggest Landfill Gas Waste to Energy Project in the Middle East Installed in Amman, Jordan
}

\author{
Constantine Hadjidimoulas \\ Independent Researcher/Student, Lorton, VA, USA \\ Email: conhadlj@gmail.com
}

How to cite this paper: Hadjidimoulas, C. (2018) Methane Gas Emissions: Methods of Improving the Efficiency of the Biggest Landfill Gas Waste to Energy Project in the Middle East Installed in Amman, Jordan. Open Access Library Journal, 5: e4476. https://doi.org/10.4236/oalib.1104476

Received: March 7, 2018

Accepted: August 28, 2018

Published: August 31, 2018

Copyright (๑) 2018 by author and Open Access Library Inc.

This work is licensed under the Creative Commons Attribution International License (CC BY 4.0).

http://creativecommons.org/licenses/by/4.0/

(c) (1) Open Access

\begin{abstract}
In a world of increasing population and consumption, there is a pressing need to use our resources in the best possible way. This involves reducing the generation of waste, achieving high-quality recycling and efficient use of the residual waste for highly productive clean energy generation. A waste-to-energy facility may generate a range of energy outputs such as electricity, district heating, steam for industrial processes and many other energy outputs. In this way, residual waste, i.e. waste that cannot be recycled in an economic or environmentally beneficial way, can become a resource by turning it into energy for the benefit of people, countries and the environment. In the last 20 years, the main waste treatment facilities are landfills. However, during this time period, there has been a huge progress and more efficient and environmentally friendly methods of waste treatment as M.B.T. (mechanical biological treatment) plants, burners, medical sterilization plants etc. are constructed, but landfills still remain the main method of waste treatment. Landfills are commonly found in developing countries. These landfills are constructed following the latest construction methods that minimize the environmental problems and maximize the energy efficiency. This research deals with the energy production of the main landfill in Amman, Jordan. The biggest waste to energy facility in the Middle East is located in Amman, Jordan. This research paper emphasizes on the problems that can occur in a waste to energy project and introduces many unique techniques that were applied in the biggest waste to energy project in the Middle East to improve and maximize the landfill gas production in the most financially and environmentally friendly way as possible. These techniques have proved that they maximize the $\mathrm{CH}_{4}$ concentration which increases the energy utilization of the landfill gas and
\end{abstract}


can, therefore, be applied in other similar projects. An image of the landfill area is shown in Figure 1.

\section{Subject Areas}

Atmospheric Sciences, Chemical Engineering \& Technology, Environmental Sciences, Industrial Engineering, Mechanical Engineering

\section{Keywords}

Renewable Energy Sources, Waste to Energy, Biogas, Environment, Methane Gas, Engineering

\section{Introduction}

As a summer engineering intern, I had the chance to be part of a waste to energy project in Amman, Jordan. The scope of this project is to extract the landfill gas from Ghabawi landfill and produce $5 \mathrm{MW}$ electrical power from it. By extracting and utilizing the landfill gas, we prevent its escape to the atmosphere, thus protecting the environment by reducing greenhouse effect due to methane $\left(\mathrm{CH}_{4}\right)$ that is the main component of landfill gas and the main gas responsible for the greenhouse phenomenon. Also, electricity is produced that helps the decrease of the consumption of conventional energy sources for electricity production.

In the $\mathrm{Al}$ Ghabawi dessert landfill, $40 \mathrm{~km}$ east of Amman, Jordan, an environmentally friendly project is taking place that involves the production of energy from waste. This landfill is the only landfill the city of Amman has. The total

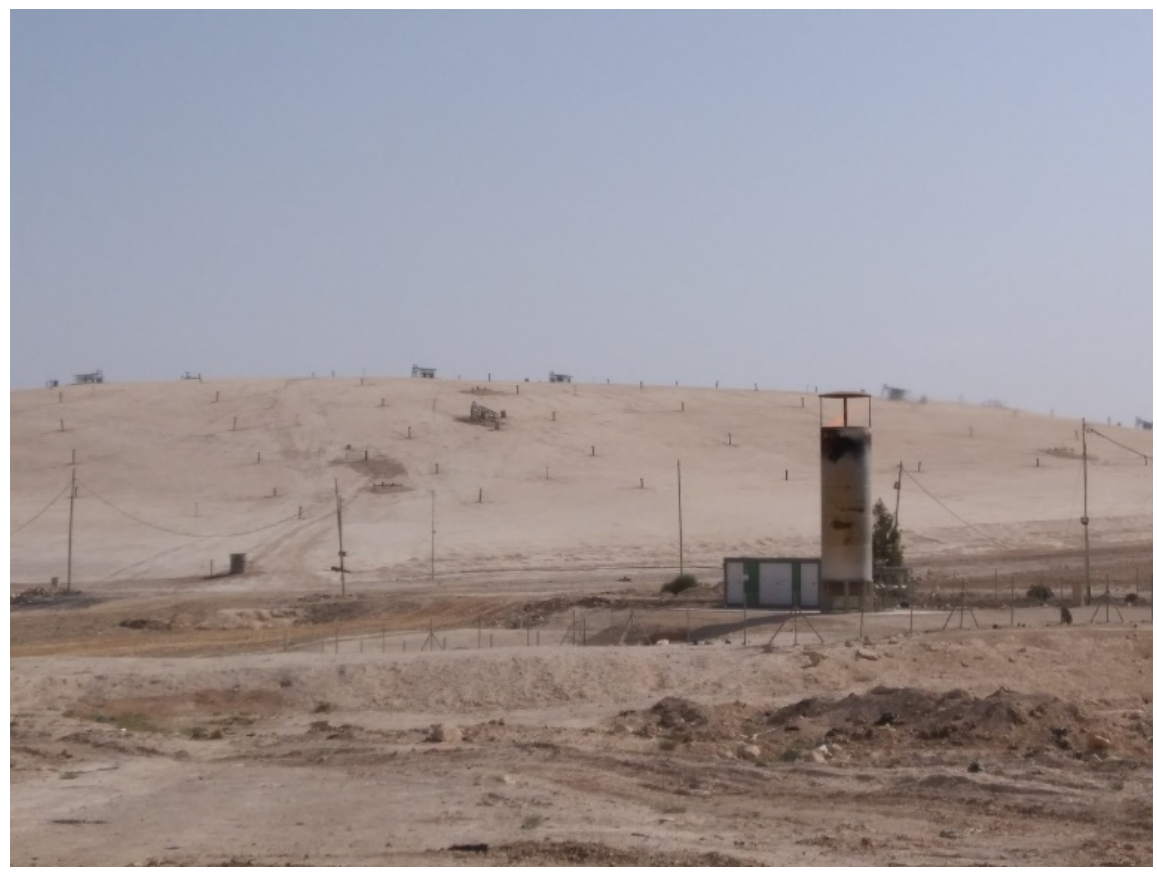

Figure 1. Photo of the main project area. 
amount of waste that has been deposited in the landfill since the landfill was created, in 2003, is more than 12,000,000 tons. Inside the waste mass in the landfill, a number of physical and chemical phenomena occur leading wastes to decomposition to their conversion in stable chemical compounds. Among others, the phenomenon of methane generation is observed, i.e. the creation and emission of biogas produced by the anaerobic degradation of the organic fraction of wastes which is mainly consisted of methane $\left(\mathrm{CH}_{4}\right)$ and carbon dioxide $\left(\mathrm{CO}_{2}\right)$. The proportion per volume of these ingredients varies between $45 \%-60 \%$ for $\mathrm{CH}_{4}$ and $40 \%-60 \%$ for $\mathrm{CO}_{2}$, while the entire process is completed through certain simultaneous stages that will be discussed later.

The project started in 2014 and it is currently in the biogas extraction phase. That means that the conversion of the biogas to electricity has not started yet and at the moment the biogas is burnt at a flare. It is very important that the Power Station starts producing electricity in 2018 as scheduled because of the energy needs the city of Amman has. The need for energy has encouraged people to find different and unique ways to supply the society with energy. This need has been more urgent for the city of Amman recently due to the increase of the population. The civil war in Syria has forced approximately 2,000,000 people to leave Syria and migrate in the capital of Jordan, in order to live a better life. This unexpected growth in the population has forced the city of Amman to find an alternative form of electricity production.

This waste to energy project is the largest project of its kind in the Middle East and the contractor is a joint-venture of two Greek construction Companies "Christopher D. Constantinidis S.A" and "HELECTOR S.A". The owner of the project is the Greater Amman Municipality (GAM) and the funding for this project came from the World Bank and the European Bank of Reconstruction and Development (EBRD). The landfill accepts only Municipal Solid Waste (MSW) which includes residential wastes, commercial wastes, and non-hazardous industrial wastes. The unacceptable wastes are hazardous-toxic waste in accordance with the reference regulatory definition in Jordan, infectious medical waste, construction and demolition debris, tires, water and wastewater treatment plant sludge dewatered to a minimum of 20 percent solids.

\subsection{Location and Topography of the Landfill}

Ghabawi landfill is located within Greater Amman Municipality in Jordan, in its Eastern part, near Jabal-Al-Ghabawi. Its distance from the center of Amman is $40 \mathrm{~km}$, whereas from Amman ring road is $23 \mathrm{~km}$. The nearest residential area is $8 \mathrm{~km}$ at the west of the landfill.

The location and the surrounding area were owned by the Jordanian military, without any residential, historical and cultural land use.

The Ghabawi landfill site is extended in an area of approximately 2,000,000

$\mathrm{m}^{2}$. Its boundaries are presented in Figure 2 and Figure 3. Figure 3 depicts the division of the landfill in 9 cells. 


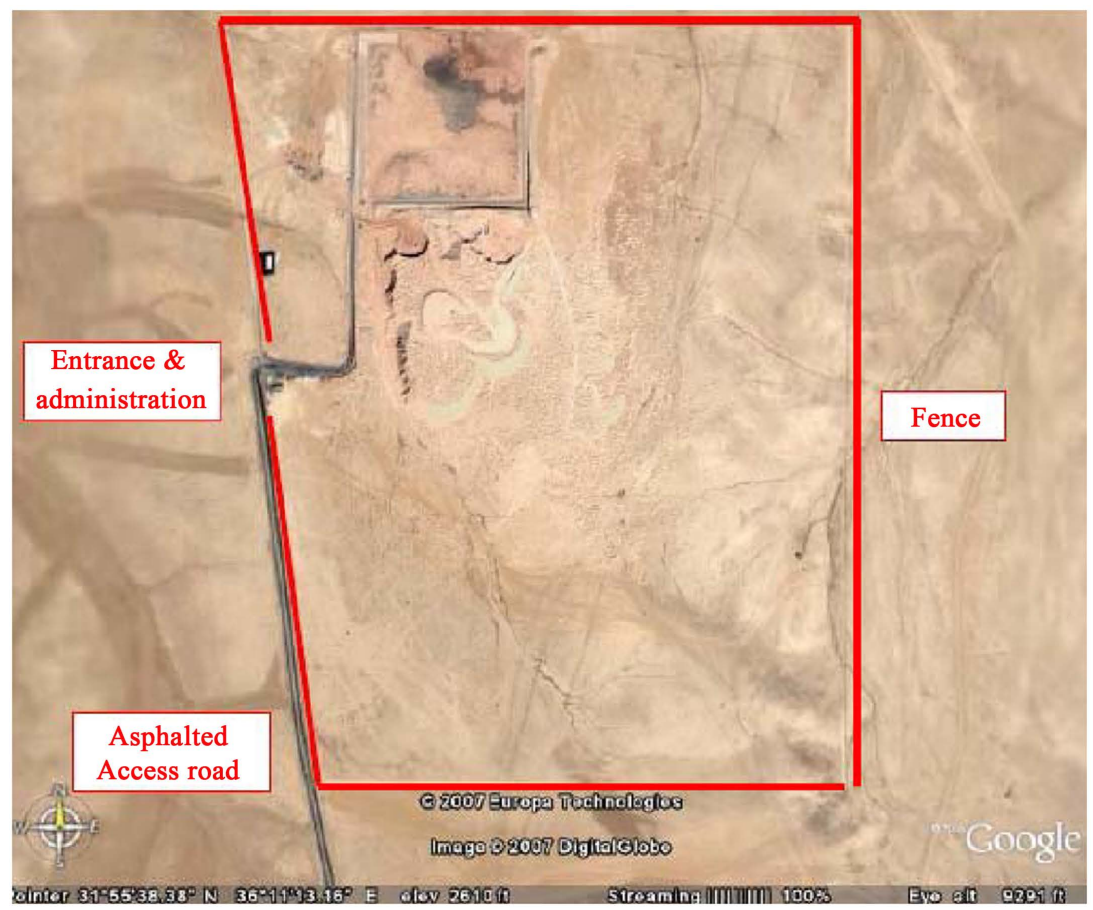

Figure 2. Boundary of the landfill.

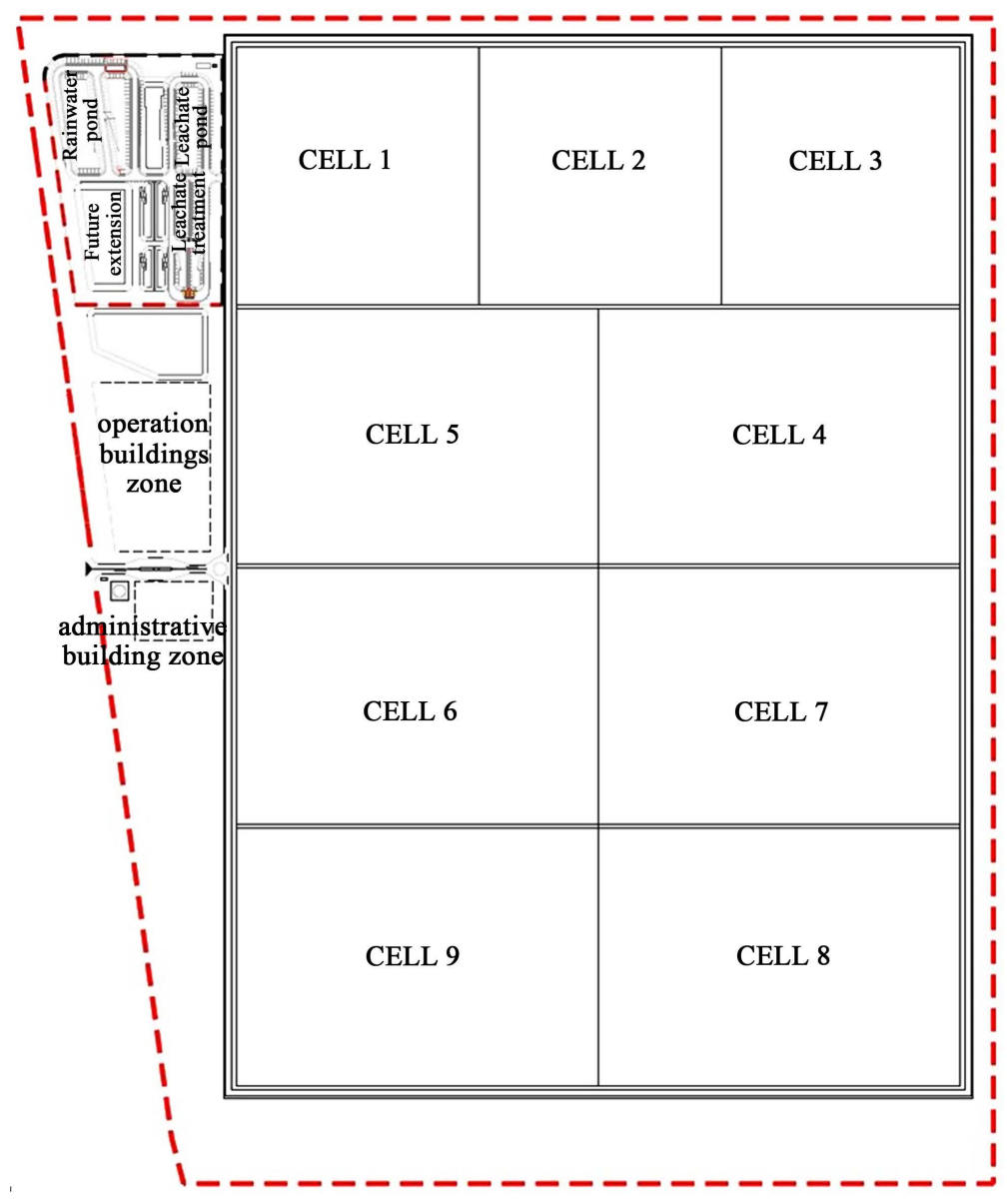

Figure 3. Depiction of the general layout of Al Ghabawi landfill [1]. 
The volumes of waste have been deposited in cells as depicted in Figure 3 (above). So far Cells 1, 2, 3 have been filled with waste and the restoration works have been completed. Landfill gas is extracted from these three cells now. At the moment, cell 4 is the active cell and it is receiving all quantities of waste from Amman municipality greater area. In the following months, the construction of cell 5 will start. When the construction is completed in cell 5 the restoration and the landfill gas extraction works for cell 4 will start and cell 5 will be the active cell receiving the income waste. Gas extraction from Cell 4 is expected to start in the first months of 2019.

\subsection{The Waste in the Landfill}

The Ghabawi landfill serves the Greater Amman Municipality, Zarqa, and Ruseifeh Municipalities (mostly via a transfer station) and some private companies, hospitals, universities and the Army. The waste quantity received at the landfill on a daily basis is measured by a single weighbridge which was recently connected to a computerized management system. The landfill accepts only Municipal Solid Waste (MSW) which includes residential wastes, commercial wastes, and non- hazardous industrial wastes. The unacceptable wastes are hazardoustoxic waste in accordance with the reference regulatory definition in Jordan, infectious medical waste, construction and demolition debris, tires, water and wastewater treatment plant sludge dewatered to a minimum of 20 percent solids. More precisely, from August 2007, according to the internal regulation, the Solid Waste Materials that are banned from Ghabawi Landfill are: Chemical materials (Acids, Chlorine, etc.), Oils, Polyester, Alkaline materials, Liquid materials (shampoo, mineral water, etc.), Flammable and explosive materials, Iron, Wood, Tires and Nylon, Plastics, and Cardboard and Paper. Some of these materials are banned because of their hazardous properties, and others because they constitute recyclable materials and GAM intends to promote recycling. In that way, full loads of recyclable materials are refused to be dumped.

The daily waste quantity that is received in the landfill is about $3.500 \mathrm{tn} /$ day. The annual quantities of waste received at Ghabawi landfill for the period from 2003 until today are presented in the following Table 1.

Table 1 serves to show the increasing waste the Ghabawi landfill receives each year. The Ghabawi landfill as mentioned above has 3 cells, full and closed. The restoration works (reshaping and final capping) of Cells No. 1, 2 and 3 were completed in March 2017 together with the gas extraction and leachate recirculation operations. Also, a flare system was installed in order to burn the extracted landfill gas. After that date, the operation period started. Regular measurements that are taking place daily are essential in order to make sure that the project is headed in the right direction and help the engineers figure out solutions for the problems that might occur. I worked during this period and I had the opportunity to take the necessary measurements, fill the reports and analyze these measurements. 
Table 1. Amount of waste received in the landfill each year [2].

\begin{tabular}{cc}
\hline YEAR & AMOUNT OF WASTE (TN) \\
2003 & 447,945 \\
2004 & 696,293 \\
2005 & 752,688 \\
2006 & 785,987 \\
2007 & 795,188 \\
2008 & 742,888 \\
2009 & 892,464 \\
2010 & 966,658 \\
2011 & 937,645 \\
2012 & 995,907 \\
2013 & $1,048,612$ \\
2014 & $1,121,540$ \\
2015 & $1,172,980$ \\
2016 & $1,344,017$ \\
2017 (up to June 2017) & 850.000 \\
\hline
\end{tabular}

The next Phase of the project ( $3^{\text {rd }}$ phase) is expected to start in August 2017. The $3^{\text {rd }}$ phase consists of the procurement and installation of the electric Power Station (total capacity of approximately $5 \mathrm{MW}$ ) and their auxiliary equipment (chillers, transformers, middle voltage electric boards and equipment, blowers, etc.) as well as the permanent installation equipment necessary to transfer the produced electric energy to the supply grid. The electricity produced will be sold to the Jordanian Electric Power Company (JEPCO) which is in charge of supplying Jordan with electric energy.

\section{Restoration of the Landfill}

The restoration of the landfill is a very complicated process. The purpose of the restoration works is to insulate the landfill in order to avoid the escape of the landfill gas to the atmosphere. That is crucial for avoiding the environmental pollution from the landfill gas and increasing the quality and quantity of the extracted gas that is used for the producing electrical energy so is increasing the income from the sale of the electrical energy. The time needed for the execution of the restoration works depends on the size of the landfill. More specifically the restoration works, for the Ghabawi landfill needed approximately 6 months/cell for the first 3 cells. However, cell 4 is slightly bigger than the previous three cells so it is expected that the restoration time plan will exceed the 6 months.

The restoration works are divided into 4 stages with very important environmental results as shown in the following Table 2. 
Table 2. The 4 stages of restoration and their results.

\begin{tabular}{|c|c|}
\hline RESTORATION WORK & RESULT OF ACTION \\
\hline 1) Overlays-landscaping & $\begin{array}{l}\text { New contour, aesthetic improvement, } \\
\text { Covering of waste, } \\
\text { Reshaping to maximum slopes of } 1 / 3(33 \%) \\
\text { for stabilization reasons and risk deduction for gas extraction }\end{array}$ \\
\hline 2) Final capping & $\begin{array}{l}\text { Obstruction of water from entering the landfill } \\
\text { Prevention of leaks of Landfill gas and odors to the atmosphere. } \\
\text { Limiting of the potential for fires }\end{array}$ \\
\hline $\begin{array}{l}\text { 3) Landfill gas extraction, } \\
\text { collection, and transfer }\end{array}$ & $\begin{array}{l}\text { Odour control, } \\
\text { Reduction of } \mathrm{CH}_{4} \text { emissions } \\
\text { Production of energy }\end{array}$ \\
\hline $\begin{array}{l}\text { 4) Extraction and } \\
\text { Recirculation of leachate }\end{array}$ & $\begin{array}{l}\text { Control of water pollution, } \\
\text { Improvement of } \mathrm{CH}_{4} \text { production with energy proposes. }\end{array}$ \\
\hline $\begin{array}{l}\text { 5) Monitoring LFG migration } \\
\text { and settlement measuring }\end{array}$ & $\begin{array}{l}\text { Measuring of LFG migrations to areas outside the landfill } \\
\text { and measuring of settlement in different areas of the landfill }\end{array}$ \\
\hline
\end{tabular}

In addition to the above environmental benefits, the production of electrical energy provides income for the Owner and makes the project financially feasible. Electricity is expected to be produced in 2018. An overall presentation of the procedure of how the gas is collected and how it is converted to electricity is depicted in Figure 4.

The restoration works that were executed in Ghabawi landfill and mentioned in Table 2 are described in detail in the following paragraphs:

\subsection{Overlays-Landscaping}

Before the construction of the works associated with Final Capping, LFG and Leachate Networks, it was required to execute earthworks with the necessary equipment in order to bring all cells to the appropriate condition that is:

- All waste must be covered with soil;

- The slopes should not exceed $33 \%$.

Table 3 shows the materials and the operation of the layers.

\subsection{Final Capping}

The final capping of cells 1, 2, 3 was the main rehabilitation element and the main roles of the final capping are:

- Minimization of infiltration by surface water into wastes, in order to improve control over the produced leachate,

- Maximization of surface run-off and drainage of the final contour,

- Control over biogas leaks,

- Creation of a natural barrier between wastes and the environment.

In order to achieve the above objectives, it was customary, in accordance to the best engineering practices, to construct multi-layered final capping, which includes the following layers, starting from the wastes and moving upwards, with the respective functions: 


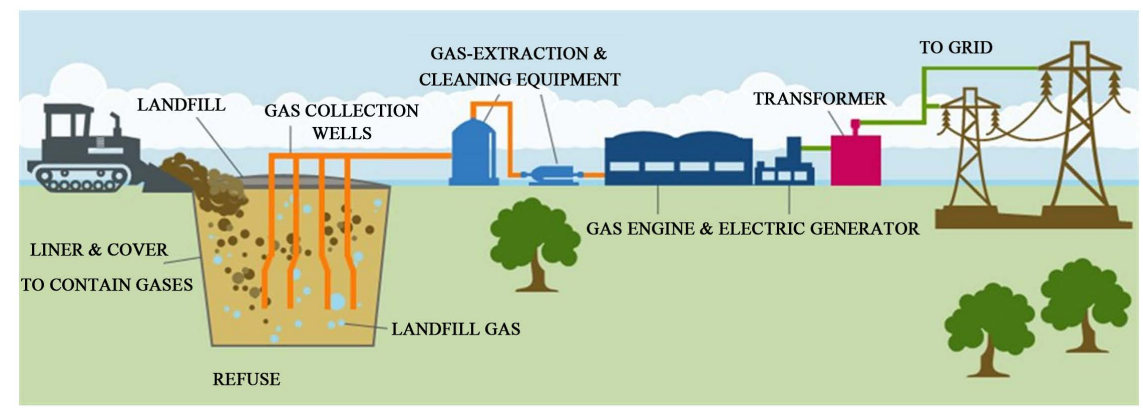

Figure 4. Process of converting biogas to electricity [3].

Table 3. Materials and operation of the layers.

\begin{tabular}{|c|c|c|}
\hline Layer & Operation & Usual materials \\
\hline Smoothing & $\begin{array}{l}\text { Smoothing of waste contour } \\
\text { in order to construct the final } \\
\text { capping-provisional capping. }\end{array}$ & $\begin{array}{c}\text { Soil materials of } \\
\text { average permeability }\end{array}$ \\
\hline $\begin{array}{l}\text { Low } \\
\text { permeability }\end{array}$ & $\begin{array}{c}\text { Interruption of surface } \\
\text { water ingress into wastes. }\end{array}$ & $\begin{array}{c}\text { Geosynthetic } \\
\text { Clay Liner (GCL). }\end{array}$ \\
\hline Drainage & $\begin{array}{l}\text { Controlled run-off of rainwater outside the final } \\
\text { contour. Reduction of hydraulic elevation } \\
\text { above the low permeability layer. Connected to } \\
\text { respective works for arranging rainwater. }\end{array}$ & $\begin{array}{c}\text { Draining } \\
\text { material (gravel) }\end{array}$ \\
\hline Protection & $\begin{array}{l}\text { The barrier between the capping layers and the } \\
\text { overlaying new uses (vegetation, etc). } \\
\text { Protection of underlying from the root } \\
\text { system of plants and from exposure. }\end{array}$ & $\begin{array}{c}\text { Clean } \\
\text { soil materials. }\end{array}$ \\
\hline
\end{tabular}

The layering of the final capping is shown in the drawing of the detailed design below. Specifically, all layers on the top of the cell are the same with the layers on the slopes and follow the same specifications (thickness, quality, water permeability etc.)

Description of Figure 5:

1) Above the soil material for the waste cover as well as the top formation layer a layer for smoothing the contour was placed, made from homogeneous materials of increased granulometry, with a diameter of $15 \mathrm{~cm}$ max, and of average $50 \mathrm{~cm}$ thickness.

2) The above is then followed by a barrier layer made of geosynthetic clay lining (GCL) of $7 \mathrm{~mm}$ thickness and of low water permeability, $5 \times 10^{-11} \mathrm{~m} / \mathrm{sec}$.

3) Then, gravel material shall be layered (drainage layer) of granulometric class $20 / 40$ and of $20 \mathrm{~cm}$ thickness, with water permeability rate between $1 \times 10^{-2}$ $-1 \times 10^{-3} \mathrm{~m} / \mathrm{sec}$

4) This was followed by separating geotextile, weighing $200 \mathrm{gr} / \mathrm{m}^{2}$, used for protecting the overlaying layer against the draining layer.

5) Afterwards, a protection layer was placed, made from uniformed materials of increased granulometry with $15 \mathrm{~cm}$ maximum diameter and $100 \mathrm{~cm}$ thickness. 


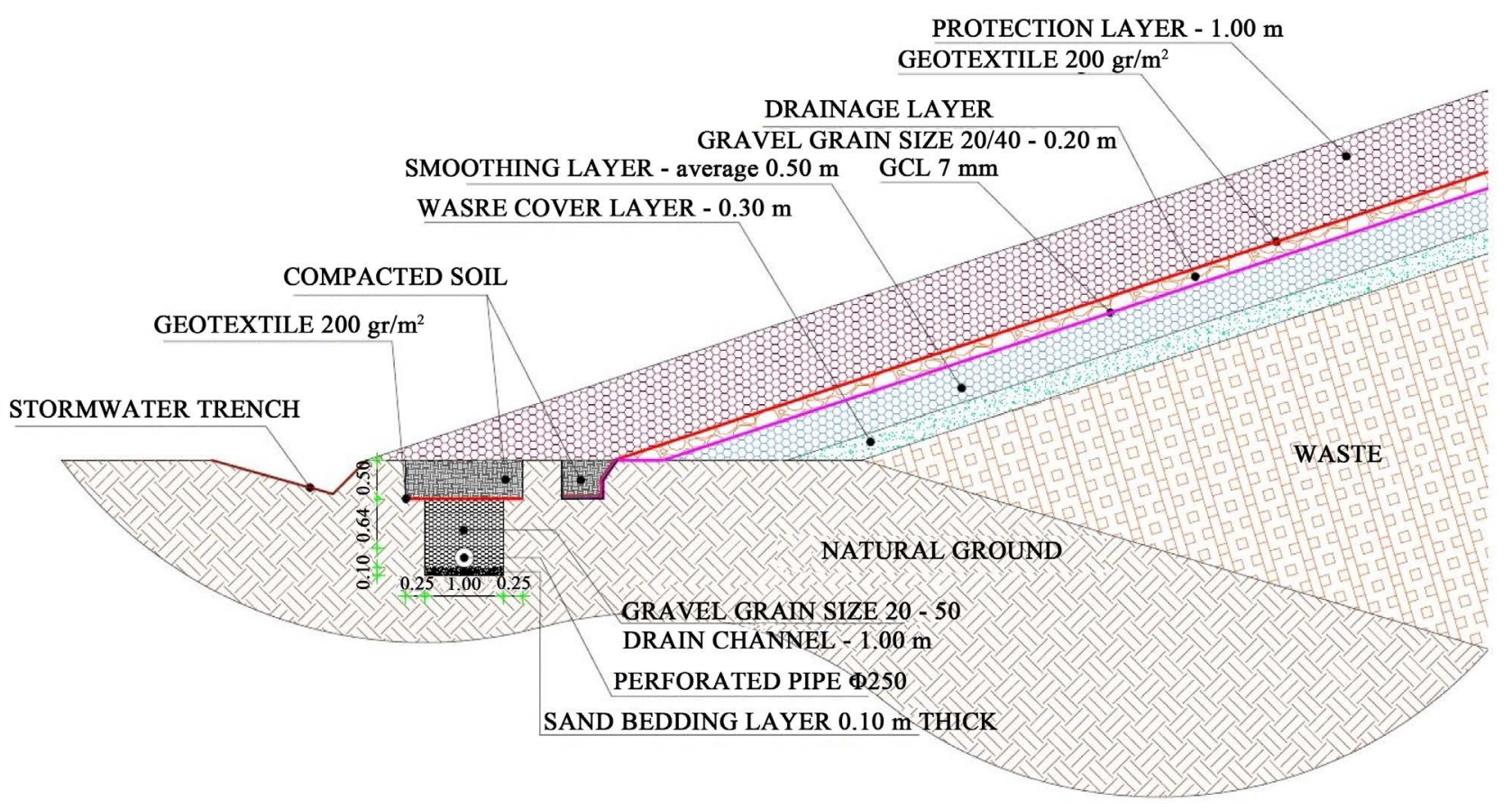

Figure 5. Layer of final capping [1].

\subsection{Landfill Gas Extraction, Collection, and Transfer}

The landfill gas is extracted from the vertical wells that were drilled by a specialized drilling machine as is shown in the following picture. The gas wells are constructed using $600 \mathrm{~mm}$ diameter (nominal) boreholes. The whole landfill gas network is constructed by HDPE. (High-density polyethylene or polyethylene, it is a polyethylene thermoplastic made from petroleum).

Depicted in Figure 6 an HDPE pipe having an outside diameter of $160 \mathrm{~mm}$, drilled in a pattern designed to optimize methane recovery is inserted vertically in the borehole and surrounded by gravel that acts as a filter to prevent solids from being ingested. The gravel was $25 / 50 \mathrm{~mm}$ granulometry of non-carbonic origin (limestone less than 25\%).

The annulus around the top of the well was backfilled and sealed with clay or bentonite ( $2.5 \mathrm{~m}$ thickness) starting $1.5 \mathrm{~m}$ below the GCL layer to prevent the escape of landfill gas. The last $20 \mathrm{~cm}$ until the top of the well is filled with compacted soil.

The top $4.2 \mathrm{~m}$ of the HDPE pipe is non-perforated to ensure the prevention of escape of landfill gas and also for safety reasons, preventing suction of atmospheric air, because the mixture of air and landfill gas at specific ratio can become explosive. The rest of the pipe is perforated with holes with diameter 12 - 14 $\mathrm{mm}$. The Depth of the wells varies according to location and it must be always 2 - 3 meters above the bottom of the landfill. The project consists of 188 wells in cell 1, 157 wells in cell 2 and 192 wells in phase 3, for a total of 537 wells. A typical detail of the landfill gas well is shown in the following drawing. The vertical section of each well is made by HDPE PN10 DN160 pipe and of a galvanized 


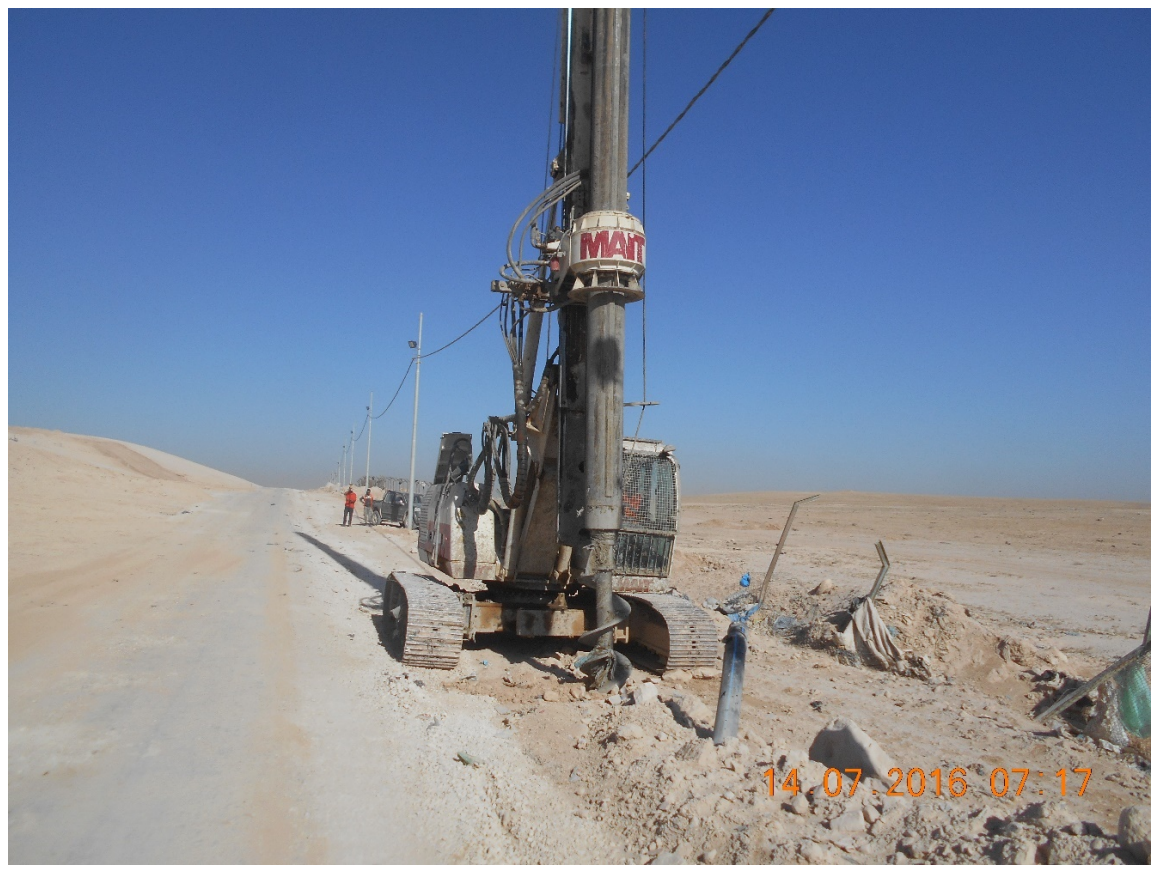

Figure 6. Machine used for drilling of the wella.

wellhead that permits the easy opening of the well in order to insert a submersible pneumatic pump to drain the leachate from flooded wells. Each wellhead has a sample point for the measuring of the landfill gas concentration as seen in Figure 7.

In order to simplify the operation Individual wells are grouped in well stations (manifolds) that are shown in Figure 8.

The maximum distance between a well and its associated well station is $85 \mathrm{~m}$ and the horizontal piping between wells and well stations is made by HDPE PN10 DN90 pipe. The well stations feature a dedicated gate valve for each well, for flow regulation purposes. They also include sampling points for the measuring of the landfill gas concentration and flow. Both wellheads and well stations are manufactured out of hot dip galvanized steel pipe with flanged connections between steel and plastic pipes. The above ground equipment (wellheads and manifolds) are not made of HDPE but of galvanized steel due to the fact that HDPE is not suitable for explosion to the sun for a long period and at this area the days of sunshine more than 300days/year. A typical manifold design is shown in Figure 9.

The horizontal piping between manifolds and the flare was manufactured of HDPE PN10 of various diameters (max. diameter DN 560). In the next face, a power station of approximately $5 \mathrm{MW}$ will be installed for the landfill gas utilization.

\subsection{Extraction and Recirculation of Leachate}

\subsubsection{Leachate Extraction}

For the extraction of the leachate from the inside of the landfill 16 extraction 


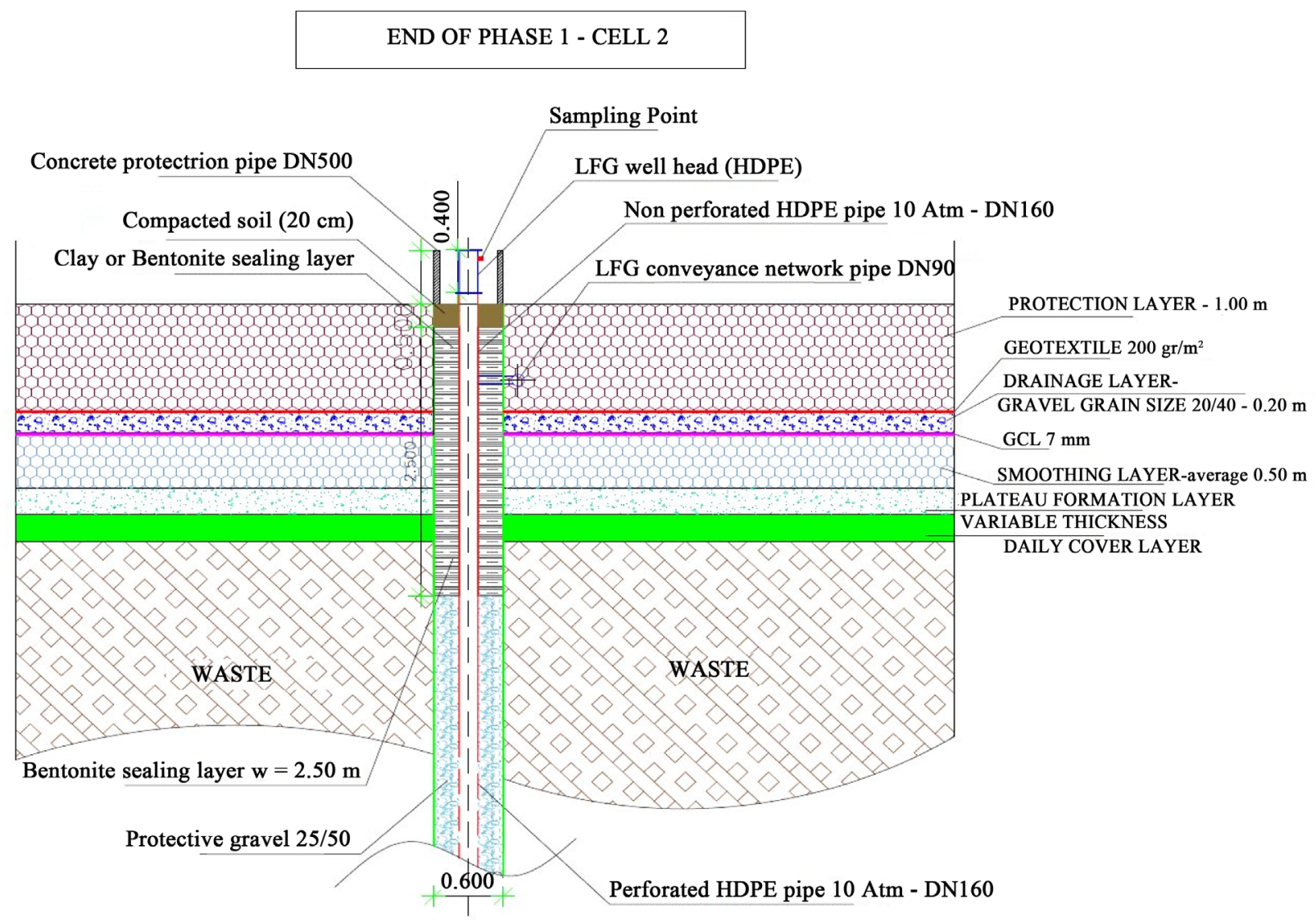

Figure 7. Parts of the well.

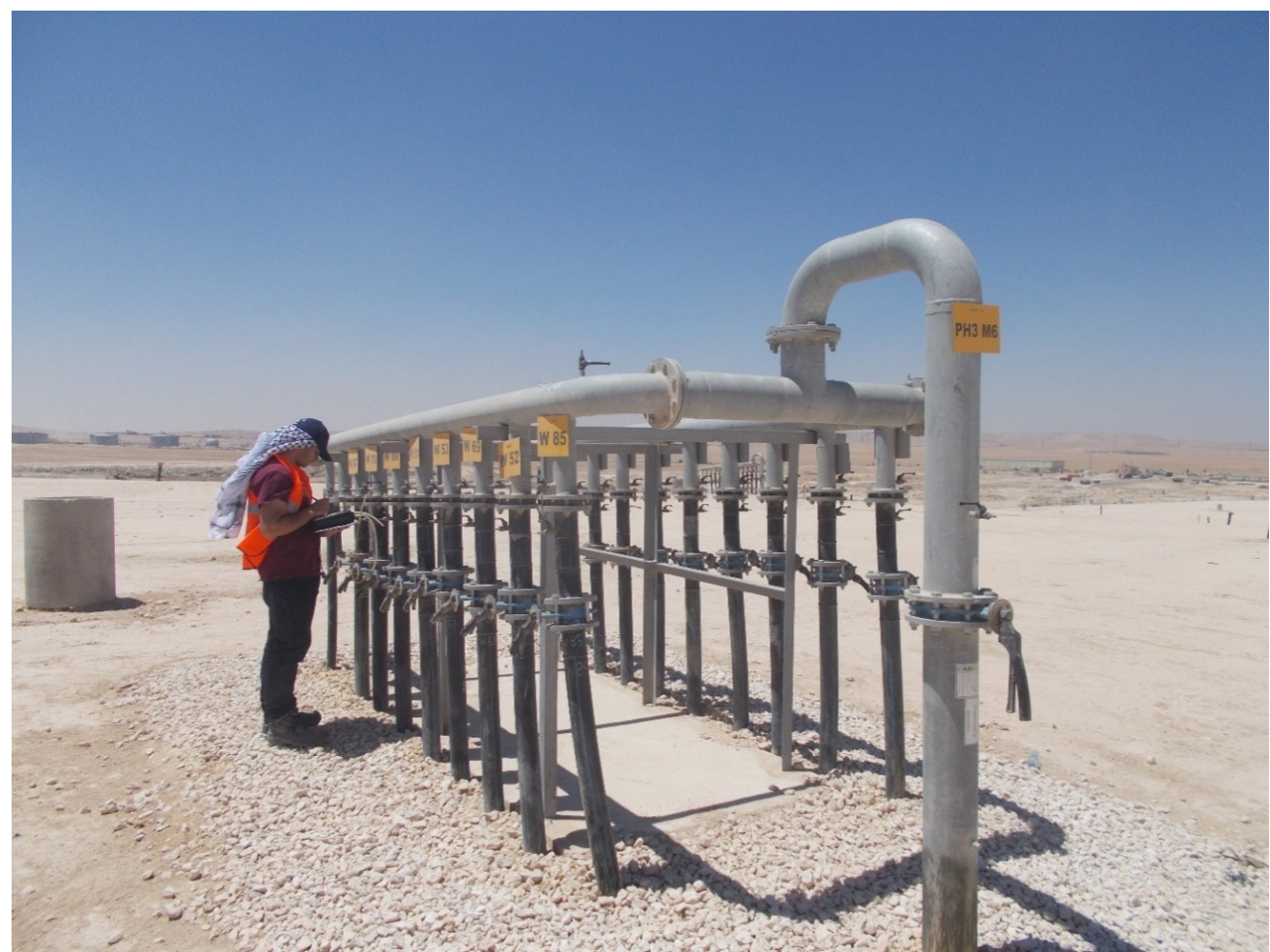

Figure 8. Measurement of gas concentration in the manifolds. 


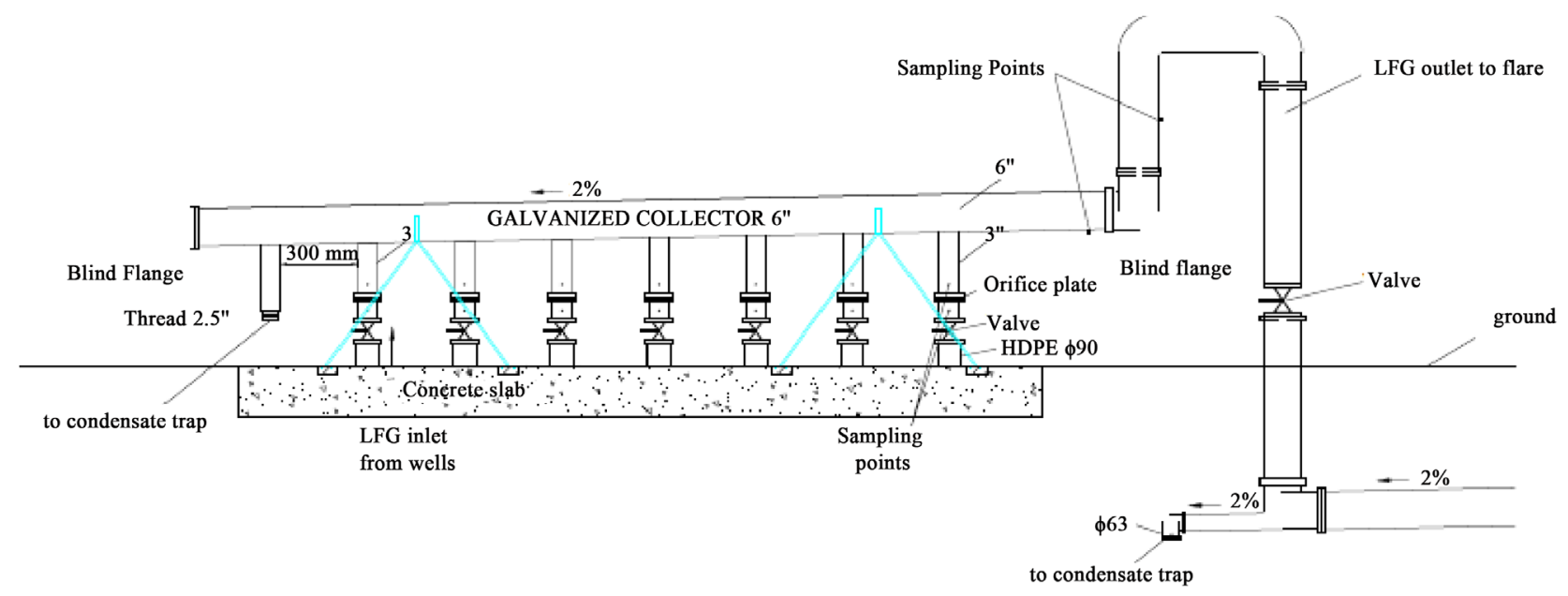

Figure 9. Typical drawing of manifold [1].

wells are installed in various positions. In each well, a pump is installed to pump the leachates from the bottom of the landfill to the surface. The position of all pumps was decided during the construction works and specifically during the drilling of the LFG wells. During the drilling of the LFG wells, the quantities of leachate in the wells were reported so the areas with larger amounts of leachate were identified and in these areas the leachate extraction wells were drilled.

\subsubsection{Leachate Recirculation}

In recent years, leachate recirculation has found widespread applications and continues to gain acceptance as a viable leachate treatment option. In fact, several full-scale recirculation sites throughout the world, presently are evaluating the performance of various recirculation systems.

These studies and research on leachate recirculation have generally reported benefits to landfill operations including an increased rate of refuse decomposition and landfill stabilization, reduction of leachate strength and associated leachate treatment cost, as well as increased methane gas production.

During the early stages of landfill operation, the leachate contained significant amounts of TDS (total dissolved solids), BOD5 (Biochemical Oxygen Demand), COD, nutrients and heavy metals. COD or Chemical Oxygen Demand is the total measurement of all chemicals (organics \& in-organics) in the water and in the wastewater.

BOD is a measure of, the amount of oxygen that requires for the bacteria to degrade the organic components present in water/wastewater.

The ratio of BOD/COD is about; COD is higher than that of BOD; maximum of up to 4 times in medium scale industries; but it varies based on the industrial process and nature of the raw materials used.

When the leachate is recirculated, the constituents are attenuated by the biological activity and by other chemical and physical reactions occurring within the landfill. For example, the simple organic acids present in the leachate are being converted to $\mathrm{CH}_{4}$ and $\mathrm{CO}_{2}$. Because of the rise in $\mathrm{pH}$ within the landfill 
when $\mathrm{CH}_{4}$ is produced, metals are precipitated and retained within the landfill. An additional benefit of leachate recycling is the recovery of landfill gas that contains $\mathrm{CH}_{4}$. Typically, the rate of gas production is greater in leachate recirculation systems. For the $\mathrm{Al}$ Ghabawi landfill, a vertical recirculation system consisted of a number ( 37 wells) was constructed for the 3 cells (Cell $1=11$, Cell $2=$ 12 , Cell $3=15$ ). The installation of the wells was conducted by excavating a hole $1.20 \mathrm{~min}$ diameter and $3.5 \mathrm{~m}$ (below the lowest layer of the top cover) deep in the refuse. A High-density polyethylene (HDPE) pipe of $110 \mathrm{~mm}$ was installed in the center of the excavated holes shown in Figure 10.

Gravel backfill is installed to ensure uniform distribution of leachate at the refuse surface. A bentonite seal is installed at the well top to seal the cap against any leachate backup. These vertical systems are connected with a horizontal piping installation, above the top cover ground, which transfers the recirculated leachate from the filtration pond of the leachate treatment plant to the wells. In order to provide the necessary pressure to guide the leachate to the wells, a pumping station was constructed where submersible pumps are installed. This design provides the ability to recirculate leachate to each cell independently (for example recirculate only to cell 1 and not to the other 2 cells) and to control the quantity of recirculated leachate in relation to the produced landfill gas.

\subsection{Emergency Leachate Storage Ponds}

In order to deal with leachate flowing from the cells on the western border, 4 emergency leachate storage ponds were constructed in the beginning of 2007.

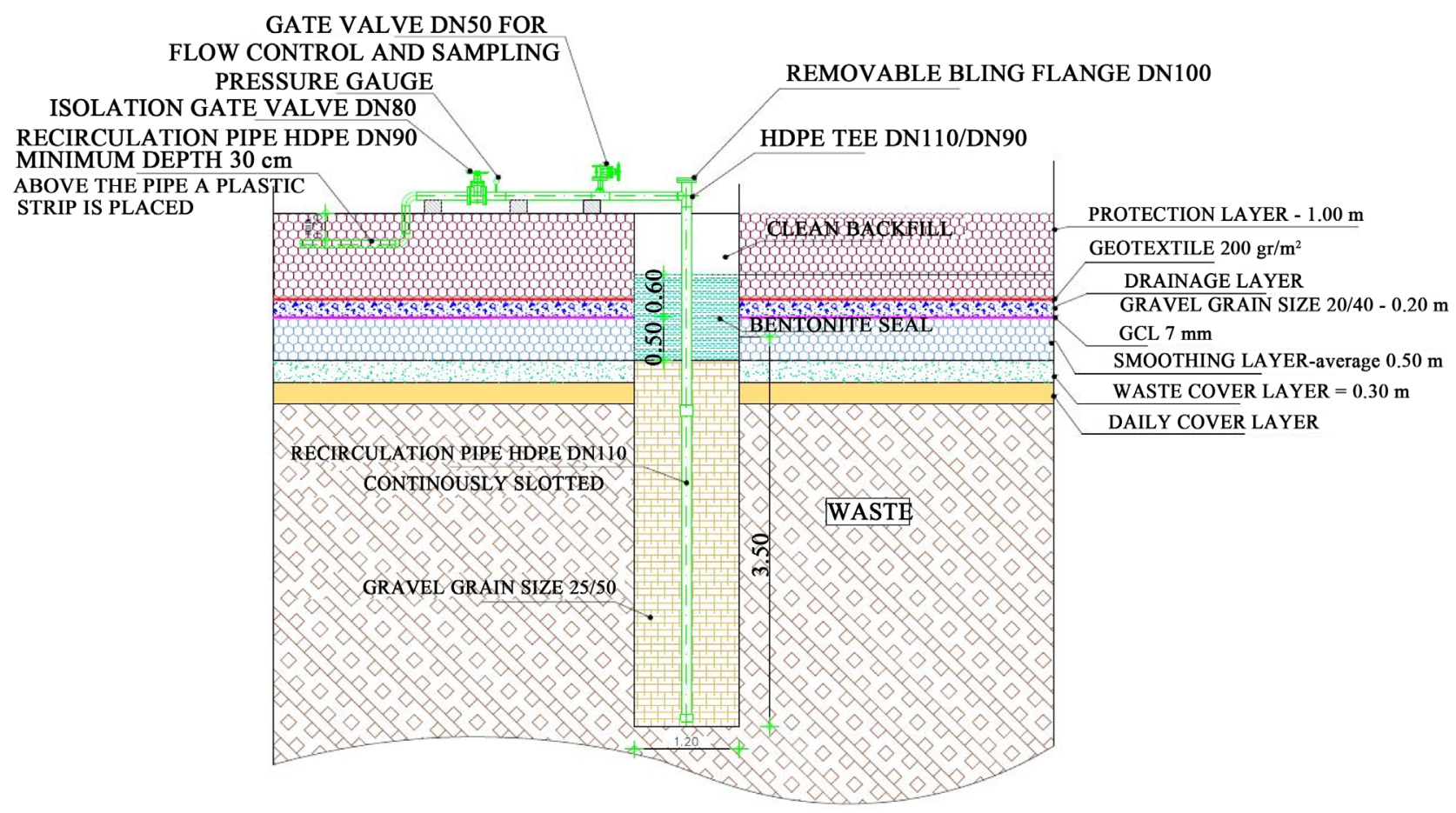

Figure 10. HDPE pipe [1]. 
For months, only about $60 \%$ - $70 \%$ of their storage capacity was used, but since December 2007, they are used to their maximum capacity.

Nevertheless, these ponds, shown in Figure 11, have not been constructed in a proper way: collapsing in some parts, one $1 \mathrm{~mm}$ HDPE geomembrane with nor GCL or protection geotextile.

Thus, these ponds should be considered only as temporary ponds. In the future, a new leachate treatment plan will be constructed in order to utilize the leachate and produce water for the landfill needs.

\subsection{Monitoring LFG Migration and Settlement Measuring}

Biogas production inspection is an indivisible section of the safe landfill operation. It must be continued until the produced gas is not a hazard for the surrounding area. For the proper environmental inspection of the landfill, 22 biogas monitoring (detection) boreholes are installed around the landfill outside the cell limits in order to identify the landfill gas migration outside the landfill by measuring the $\mathrm{CH}_{4}$ concentration at the air inside those boreholes.

Furthermore, 132 settlement markers are installed in all cells in order to measure the settlement of different areas in the landfill on a regular basis. Important Settlements may cause damages at the underground LFG pipes so repair works should be performed

\subsection{Production Stages of LFG}

Biogas production in a landfill is performed through five more or less distinct stages:

\section{Stage 1: Adjustment stage}

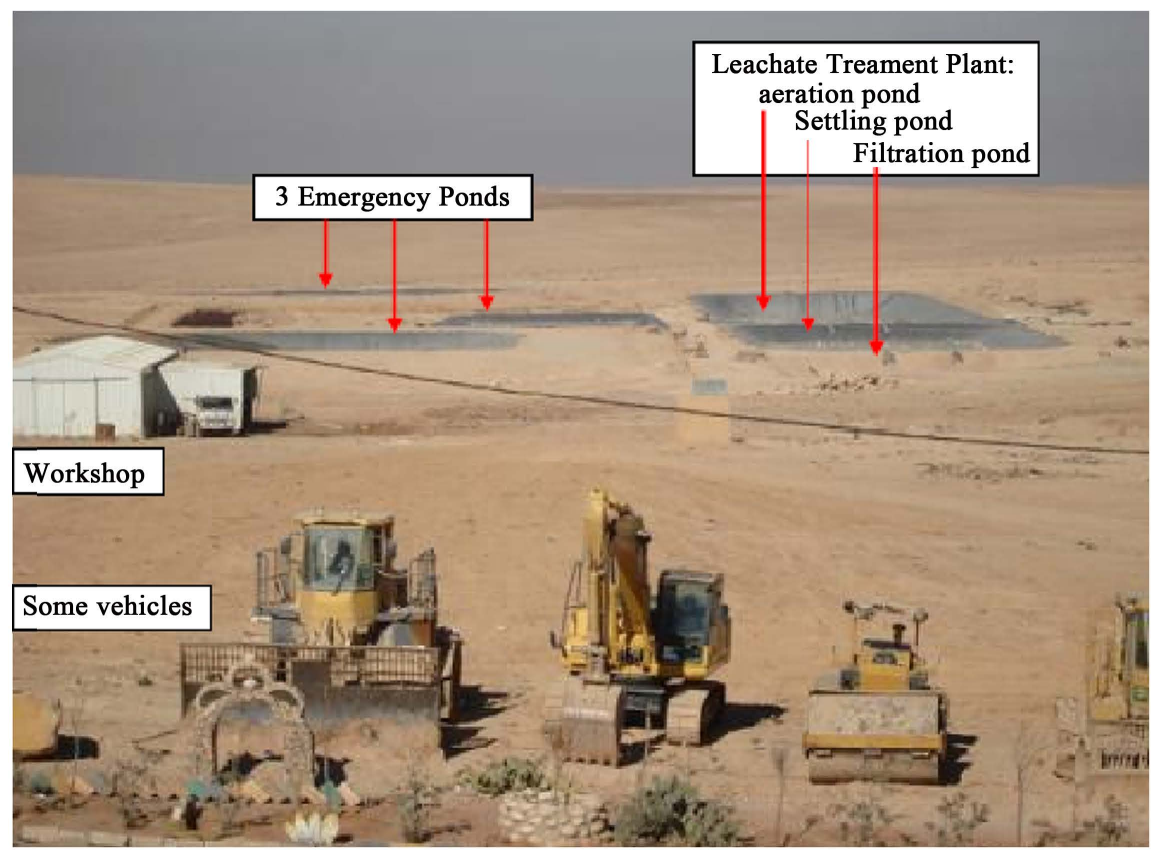

Figure 11. Emergency ponds. 
The organic content of wastes is degraded under the effect of microorganisms immediately after being disposed of in the landfill. At this stage, the biological degradation is aerobic, due to the air captured inside the waste mass. The microorganisms causing the anaerobic or aerobic degradation come from the soil, which is used in order to cover the wastes on a daily basis, as well as from the biological sludge if this is made available along with the wastes and finally by the leachate when it re-circulates inside the waste mass.

\section{Stage 2: transition stage}

In the second stage, oxygen is consumed and the anaerobic process begins. During the anaerobic process, nitrogen and sulfur are converted to gaseous nitrogen and sulfuric hydrogen respectively by receiving electrons. At this stage, the redox potential is approx. -50 to -100 millivolts. Methane is produced when the redux potential lies between -150 and -300 millivolts. While the reduction of potential continues, the microorganisms responsible for producing methane and carbon dioxide start converting the organic material to organic acids, while reducing further $\mathrm{pH}$.

\section{Stage 3: Acid stage}

This stage is characterized by the formation of organic acids and hydrogen gas. The first stage refers to the degradation of organic compounds of large molecular weight into simple ones, which shall be used as a source of energy and carbon for microorganisms. In the second stage, organic acids are formed and $\mathrm{pH}$ is significantly reduced. In this stage, carbon dioxide is produced, as well as hydrogen gas. The value of $\mathrm{pH}$ of the formed leachate is lower than 5 due to the presence of organic acids. In these conditions, lots of inorganic constituents, and mainly heavy metals are dissolved and removed through leachate, as well as nutrients.

\section{Stage 4: Methane formation stage}

This is the stage where methane is formed. Another group of microorganisms converts organic acids and hydrogen to methane and carbon dioxide. These microorganisms are strictly anaerobic (methanogens or methane formers). $\mathrm{pH}$ increases in neutral conditions (6.8 - 7); the same occurs in leachate.

\section{Stage 5: Maturation stage}

This stage begins when the entire biodegradable material has been converted to $\mathrm{CH}_{4}$ and $\mathrm{CO}_{2}$. As moisture enters the waste mass, the organic material that had remained stable starts dissolving. The biogas production rate is low and mainly $\mathrm{CH}_{4}$ and $\mathrm{CO}_{2}$, are formed, as well as small quantities of $\mathrm{N}_{2}$ and $\mathrm{O}_{2}$.

The duration of each separate stage varies and depends on the quantity of the organic materials disposed of in the landfill, the availability of nutrients, the moisture of the wastes and their compression level.

\subsection{Produced Biogas Quantity}

The chemical reaction describing biogas production during the anaerobic process can be noted as follows: 
Organic material $+\mathrm{H}_{2} \mathrm{O} \stackrel{\text { MICROORGANISMS }}{\longrightarrow}$ fixed organic material $+\mathrm{CH}_{4}+\mathrm{CO}_{2}+$ other gases

The organic material located in wastes can be divided into the following two categories:

- Material which is immediately degradable (three months to five years) and

- Material that is degraded at a very slow rate (from five to more than 50 years).

The chemical equation describing the degradation of the organic material in order to produce methane and carbon dioxide is the following: Based on the above equation, and by using a different chemical formula for the fast and for the slow biodegrading material, we can calculate through stoichiometry the produced biogas quantity.

Under normal conditions, the degradation rate of wastes, measured by the produced biogas quantity, presents a maximum value in the first two years and then gradually is reduced, continuing, for certain gases, for a time period exceeding 25 years. If moisture does not enter the wastes, in regard to properly compressed wastes, it is not rare to locate materials at their initial condition several years after they have been disposed of.

As mentioned above, a section of the wastes shall be subjected to anaerobic degradation immediately after being disposed of in the landfill, while another section shall start degrading after several years. A similar progress is presented by the biogas production rate, as noted in the following Figure 12 .

As presented in Figure 13, biogas production starts on the second year after disposing of the wastes. It is estimated that biogas production starts approximately at the end of the first year of a landfill's operation and continues for several years after being filled; small quantities can be traced even 20 years after.

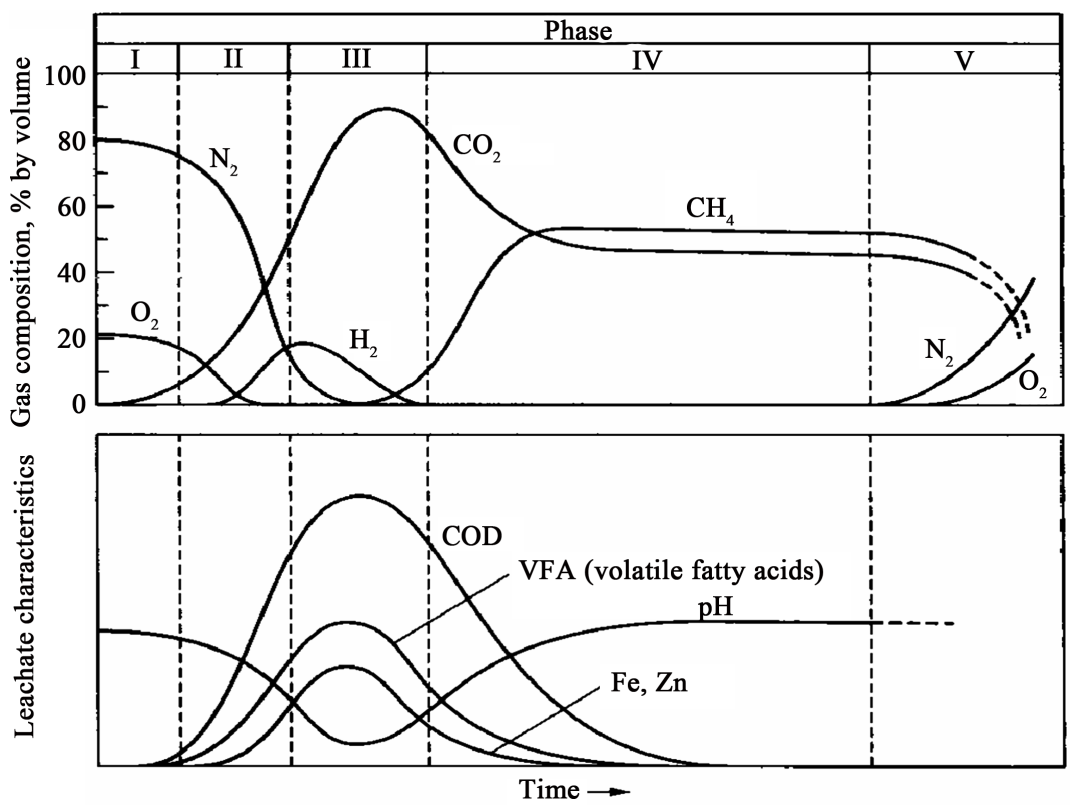

Figure 12. Schematic presentation of biogas production stages. Source: "Integrated Solid Waste Management" G. Tchobanoglous, H. Theisen, S. Vigil [4]. 


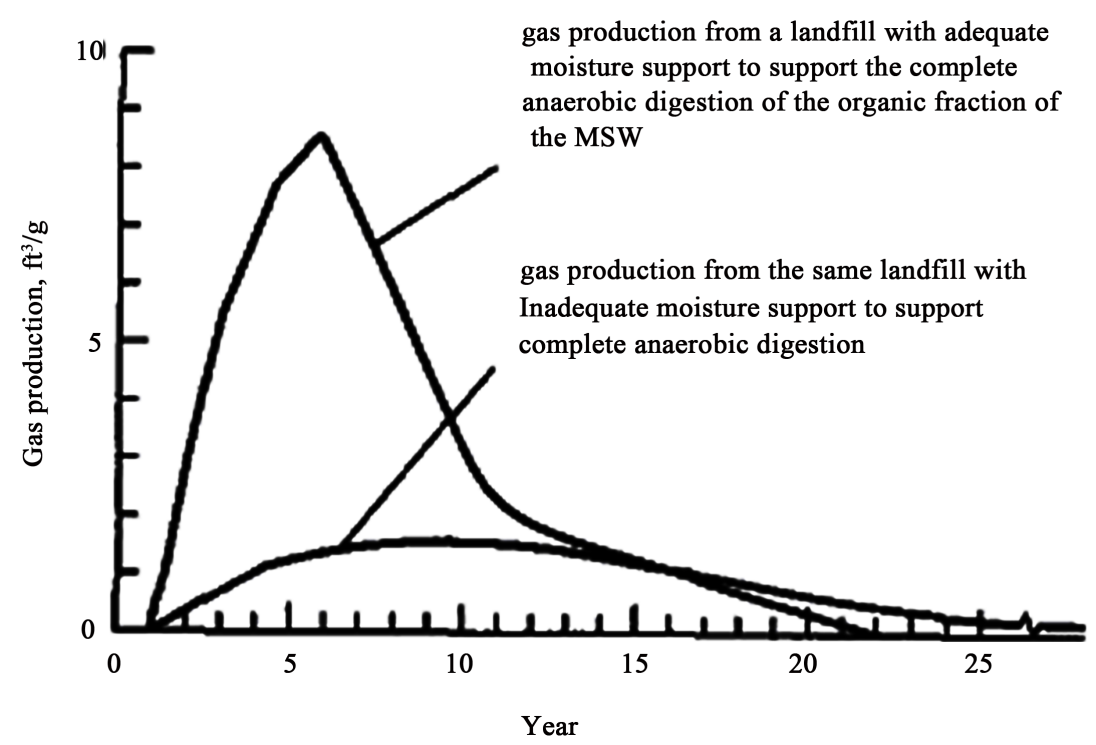

Figure 13. Effect of reduced moisture content of the production of landfill gas. Source: "Integrated Solid Waste Management" G. Tchobanoglous, H. Theisen, S. Vigil [4].

In several cases, waste moisture is not enough in order to complete their anaerobic degradation. The best moisture rate is $50 \%-60 \%$. In case of insufficient moisture, the production rate is reduced, resulting in a flatter biogas production curve, expanding to a large time period.

\subsection{Landfill Gas Production}

The production of LFG is determined from the mass of available carbon (1 mole of carbon produces 1 mole of carbon dioxide or methane). The proportion of carbon dioxide to methane for methanogenic degradation is determined using the ratio of $1 \%$, as described above. The quantity of carbon dioxide and hydrogen generated acetogenically is determined by the equation below.

$$
\mathrm{C}_{6} \mathrm{H}_{12} \mathrm{O}_{6} \rightarrow 2 \mathrm{CH}_{3} \mathrm{COOH}+4 \mathrm{H}_{2}+2 \mathrm{CO}_{2}
$$

Table 4 demonstrates the amount of the LFG produced as well as the projected amount up to the year 2028, from cell 1, 2 and 3. The LFG recovered quantity is the $75 \%$ of the estimated produced quantities and it is the amount that is expected to be utilized. This $75 \%$ is a correction factor based on the experience of the contractor.

\section{Measurements}

During my time in the project, I cooperated with two local site engineers. We were in charge of measuring the following parameters:

1) Landfill gas composition, flow, and suction at the flare (completion of Form 1)

These measurements show the quality and quantity of landfill gas that enters the flare. This form is completed daily in order to check if the landfill gas extraction in according to our expectations. 
Table 4. Landfill gas produced from cells 1, 2, 3.

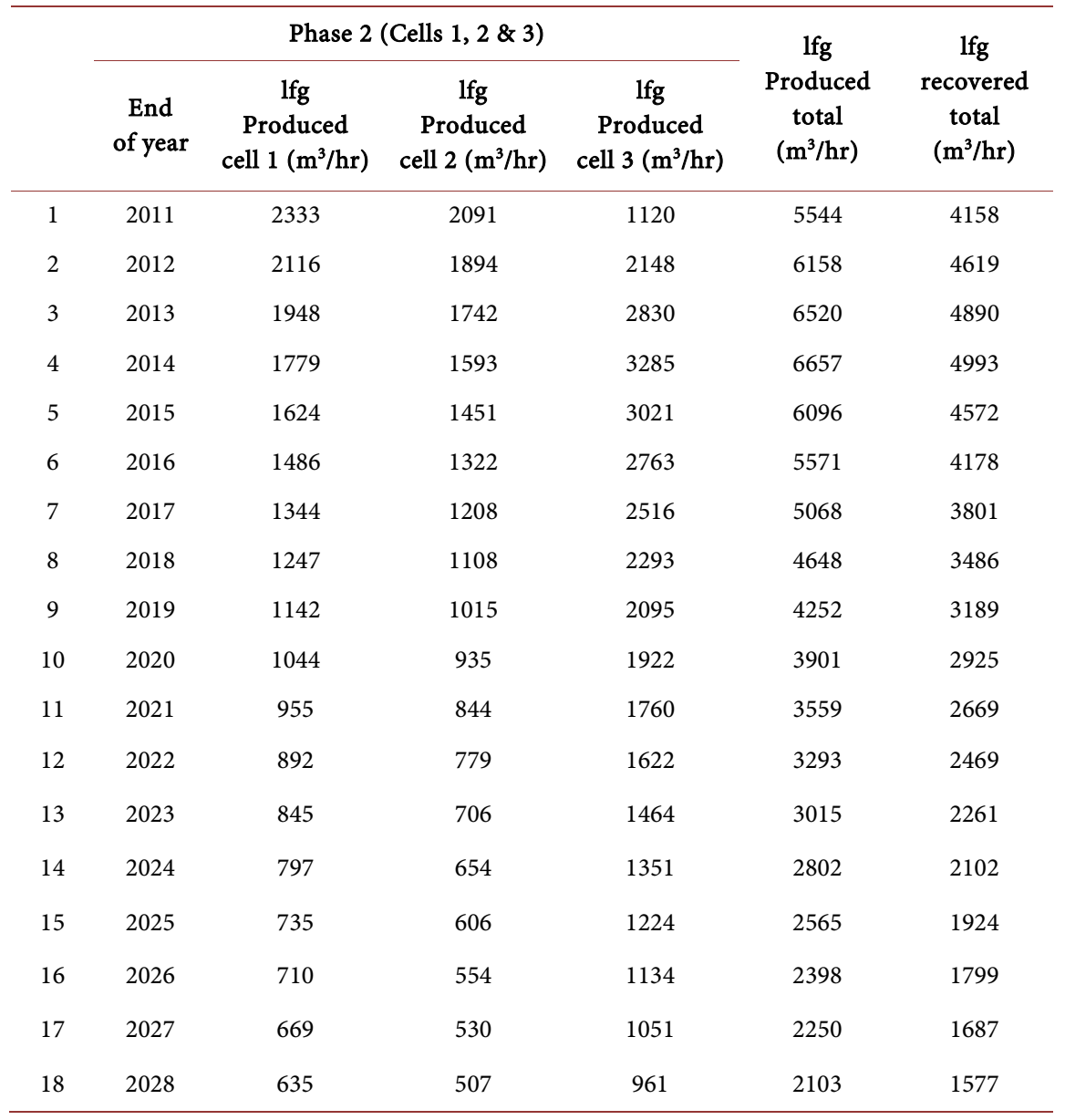

2) Landfill gas composition and suction at each manifold (completion of Form 2)

These measurements show the efficient operation of each manifold and we can identify if any problem exists at the manifold.

3) Landfill gas composition, flow, and suction of each well (completion of Form 3)

These measurements show the efficient operation of each well and we can identify if any problem exists at the well.

4) Landfill gas composition, flow, and suction of each well at the well and at the manifold (completion of Form 4).

These measurements allowed us to check everything as in form 3 but also to identify if there is a problem at the horizontal or the vertical LFG network.

5) Leachate level inside the LFG wells (completion of Form 5)

These measurements allow us to measure the leachate level inside the wells in order to decide to pump the leachate with a portable pump or not.

6) Air composition at the monitoring wells (completion of Form 6) in order to identify if any LFG migration exists outside the cell area

7) Elevation of settlement markers (completion of Form 7) in order to check 
the settlement of the landfill periodically.

A portable gas analyzer was used for these measurements and also a portable digital manometer that measures suction and differential pressure. From the differential pressure, we were able to calculate the landfill gas flow. Monitoring events should be paired with balancing activities to optimize LFG composition at individual wells and at the manifolds as relevant.

\subsection{Collection Field Monitoring and Adjustment}

The LFG collection field must be routinely monitored and adjusted to optimize the effectiveness of the collection system. The adjustment of valve settings to reduce or increase LFG flows from low or high generation areas of the landfill is required to maximize LFG collection without overdrawing from those areas of the site that may be susceptible to air intrusion. It should be noted that collection field adjustments must be made based upon a review of history of well or trench performance considered within the context of the overall field operation. Even relatively minor changes to a particular collection point will influence flow and vacuum at other locations within the collection system.

A certain amount of judgment gained from site-specific experience is required when making adjustments to the collection field. If combustible gas readings at a specific well or trench are found to be substantially below the plant gas concentration, then the flow from that well or trench should be reduced. Changes in the valve position (i.e., going from fully open to fully closed) are often counter-productive, as a given well may demonstrate high oxygen/low methane at full vacuum exertion, but reasonable gas quality at some reduced level; this reflects the purpose of well control valves. Smaller changes in valve position are more conducive to effective operations and are most useful when the history of a well relative to LFG quality and valve position are recorded and utilized to guide future balancing activities.

The above mentioned routine inspections are also conducted to characterize the condition of the closure facilities and the LFG collection network to be more precise.

Personnel of the contractor is responsible for conducting the inspection of a list of items and the suggested frequency of the inspections. Typical problems that might be observed are (Table 5):

- Odors: blower inoperable, broken gas well pipes;

- High gas readings in monitoring boreholes: failure of impermeable liners/barriers.

Provision for the insertion of a hot-wire anemometer is likely sufficient to yield velocity data if required. Generally, this information is used in field diagnostics if the conventional well field data is not able to identify the cause of an issue. Water/leachate levels in vertical gas extraction wells may also be obtained and can be important where there is a known or suspected perched leachate or leachate mound condition. Interpretation of LFG data must be undertaken with caution where water level readings indicate that the well screen is flooded, as this 
Table 5. Accepted operation limits for the major LFG parameters [2].

\begin{tabular}{cccc}
\hline \multirow{2}{*}{ Parameter } & \multicolumn{3}{c}{ ACCEPTED LFG VALUES } \\
\cline { 2 - 4 } & Flare & Manifold & Well $^{1}$ \\
\hline $\mathrm{CH}_{4}$ & $>40 \%$ & $>40 \%$ & $>35 \%$ \\
$\mathrm{O}_{2}$ & $<3 \%$ & $<3 \%$ & $<7 \%$ \\
Suction Pressure & $>-60 \mathrm{mbar}$ & $>-100 \mathrm{mbar}$ & $>-70 \mathrm{mbar}$ \\
Recording Form type & 1 & 2 & 3 \\
Frequency of Measurements & Daily & Weekly $^{2}$ & Monthly $^{3}$ \\
\hline
\end{tabular}

suggests that none of the vacuum exerted on the well is being transmitted into the waste to draw LFG (i.e., no variance in pressure on either side of the control valve). This condition is often difficult to correct, as it requires an evaluation of the leachate and surface water control systems. In some cases, inserting pumps into LFG extraction wells can reduce liquid levels, but if the liquid is associated with a leachate mound, it is unlikely that single pumps will influence the liquid profile. In addition, biogas shall be measured in the manifolds of the collection transfer network, placed inside the wastes.

The following measurements are going to be performed on the manifolds:

- Pressure (suction) measurement;

- detection of concentrations of methane, carbon dioxide, and oxygen.

\subsection{Limit Levels and Action Plan for LFG Network}

The above performance standard is not meant to be restrictive. In some cases, especially where a utilization system is in place, it may be necessary to monitor and balance on a much more frequent basis, particularly if the LFG management system is large. Daily monitoring and balancing are not uncommon at large landfills. Additionally, LFG quality and flow can be subject to a number of meteorological conditions, one of which is atmospheric pressure. It has been observed that rapid changes in atmospheric pressure can affect LFG composition and flow. For utilization systems, however, monitoring and balancing may need to respond to changes in atmospheric pressure, or even anticipate such changes by providing adjustments to well field valve settings before the pressure front arrives. There are a number of additional reasons for monitoring and balancing on a more frequent basis, and thus the performance standard for monitoring frequency should be seen as a minimum requirement. Monitoring at each collection point should begin with the measurement of vacuum pressure. A portable gas meter is then used to measure methane and oxygen composition. As good monitoring practice, combustible gas readings should not be taken until after the pressure measurements, due to the possibility of interference with pressures by the action of extracting the gas sample. If required, water/leachate levels should be taken after all gas measurements are completed, as this monitoring may require opening the LFG extraction well cap. The following Table presents a simple diagnostic tool to highlight some common problems in the operation of the LFG collection and utilization facilities and their recommended actions. Table 6 
Table 6. Non accepted measurements and how to treat them.

\begin{tabular}{|c|c|c|}
\hline \multicolumn{2}{|c|}{ Non accepted measured parameter } & \multirow{2}{*}{$\begin{array}{c}\mathrm{CH}_{4}<35 \% \\
\text { Recommended Actions }\end{array}$} \\
\hline Checked Values & Diagnosis & \\
\hline $\begin{array}{c}\text { Same recorded values of } \\
\mathrm{CH}_{4}, \mathrm{O}_{2} \text { and suction pressure } \\
\text { for both well and manifold }\end{array}$ & $\begin{array}{l}\text { There is } \\
\text { none problem } \\
\text { with the LFG } \\
\text { horizontal } \\
\text { network. } \\
\text { The problem } \\
\text { is identified } \\
\text { on LFG well }\end{array}$ & $\begin{array}{l}\text { - STEP 1: Measurement of the leachate level at the LFG Well and check } \\
\text { if the level is high }(<15 \mathrm{~m}) \text {. } \\
\text { - STEP 2: Isolation of the well from the LFG system in the case of } \\
\text { high leachate level } \\
\text { - STEP 3: Extract the leachate through a portable pump. The pumped leachate is } \\
\text { transported to the wastewater treatment plant by a tanker truck. } \\
\text { - STEP 4: This procedure of above step should be repeated until the } \\
\text { successful leachate level drop } \\
\text { - STEP 5: Measure the leachate level from the isolated well after three days } \\
\text { - } \text { STEP 6: If the leachate level is accepted, the isolated well is connected } \\
\text { again to the LFG system (through the valve at the manifold). } \\
\text { We repeat the level measure after three days } \\
\text { - STEP 7a: if the } \mathrm{CH}_{4} \text { is lower than } 35 \% \text { and leachate level is rising up again } \\
\text { (<15 m) then we repeat the above-mentioned steps as many times as required } \\
\text { - } \text { STEP 7b: if the } \mathrm{CH}_{4} \text { is lower than } 35 \% \text { and leachate level is } \\
\text { accepted then we isolate again the well from the LFG network } \\
\text { and repeat the measure after } 15 \text { days }\end{array}$ \\
\hline $\begin{array}{l}\text { - The } \mathrm{CH}_{4} \text { concentration at } \\
\text { well is higher than to the manifold } \\
\text { - The } \mathrm{O}_{2} \text { concentration at well is lower } \\
\text { than to the manifold } \\
\text { - The suction pressure at manifold is } \\
\text { lower than to the well }\end{array}$ & $\begin{array}{l}\text { The horizontal } \\
\text { LFG network } \\
\text { either is blocked } \\
\text { by condensate or is } \\
\text { partly damaged }\end{array}$ & $\begin{array}{l}\text { - STEP 1: Blowing air to the network after wellhead opened } \\
\text { STEP 2: Repeat the suction pressure measurement after few minutes. } \\
\text { If the problem continues to exist then we proceed to the } \\
\text { horizontal LFG network problematic branch repair }\end{array}$ \\
\hline
\end{tabular}

- The $\mathrm{CH}_{4}$ concentration at well is higher than to the manifold

- The $\mathrm{O}_{2}$ concentration at well is lower than to the manifold

The problem is on horizontal LFG network

- The suction pressure at manifold is equal with this at the well

- The $\mathrm{CH}_{4}$ concentration at manifold is equal with this at the well

- The $\mathrm{O}_{2}$ concentration at manifold is equal with this at the well

- The suction pressure at manifold is different to this at the well

Non accepted measured parameter Checked Values Diagnosis

Same recorded values of $\mathrm{CH}_{4}, \mathrm{O}_{2}$ and suction pressure for both well and manifold
There is none problem with the LFG horizontal network. The problem is identified on LFG well
Repair the problematic branch of the horizontal LFG network

- STEP 1: Blowing air to the network after wellhead opened

- STEP 2: Repeat the suction pressure measurement after few minutes. If the problem continues to exist then we proceed to the horizontal LFG network problematic branch repair

\section{$\mathrm{O}_{2}>7 \%$ \\ Recommended Actions}

- STEP 1: Measurement of the leachate level at the LFG Well and check if the level is high $(<15 \mathrm{~m})$.

- STEP 2: Isolation of the well from the LFG system in the case of high leachate level

- STEP 3: Extract the leachate through a portable pump. The pumped leachate is transported to the wastewater treatment plant by a tanker truck.

- STEP 4: This procedure of above step should be repeated until the successful leachate level drop

- STEP 5: Measure the leachate level from the isolated well after three days

- STEP 6: If the leachate level is accepted, the isolated well is connected again to the LFG system (through the valve at the manifold). We repeat the level measure after three days

- STEP 7a: if the $\mathrm{O}_{2}$ is higher than $7 \%$ and leachate level is rising up again $(<15 \mathrm{~m})$ then we repeat the above-mentioned steps as many times as required

- STEP 7b: if the $\mathrm{O}_{2}$ is higher than $7 \%$ and leachate level is accepted then we isolate again the well from the LFG network and repeat the measure after 15 days 


\section{Continued}

- The $\mathrm{O}_{2}$ concentration at well is higher than to the manifold

- The $\mathrm{CH}_{4}$ concentration at well is lower than to the manifold

- The suction pressure at manifold is lower than to the well

- The $\mathrm{O}_{2}$ concentration at well is higher than to the manifold

- The $\mathrm{CH}_{4}$ concentration at well is lower than to the manifold

- The suction pressure at manifold is equal with this at the well

- The $\mathrm{O}_{2}$ concentration at manifold is equal with this at the well

- The $\mathrm{CH}_{4}$ concentration at manifold is equal with this at the well

- The suction pressure at manifold is different to this at the well
The horizontal

LFG network

either is blocked

by condensate

or is partly

damaged

The problem is on horizontal LFG network

The problem is on horizontal LFG network
- STEP 1: Blowing air to the network after wellhead opened

- STEP 2: Repeat the suction pressure measurement after few minutes. If the problem continues to exist then we proceed to the horizontal LFG network problematic branch repair

- STEP 1: Blowing air to the network after wellhead opened

- STEP 2: Repeat the suction pressure measurement after few minutes. If the problem continues to exist then we proceed to the horizontal LFG network problematic branch repair

\section{Non accepted measured parameter}

Checked Values

The suction pressure at manifold is lower than to the well

\section{Diagnosis}

The horizontal LFG network either is blocked by condensate or is partly damaged

\section{Different measured Suction Pressure}

Recommended Actions

below describes some common LFG issues that occur in a landfill and how they can be repaired.

\subsection{LFG Migration Assessment and Control}

It is expected that the implementation of efficient, well-operated LFG management systems will in many cases address concerns regarding LFG migration through subsurface soils. Nevertheless, it is important to evaluate potential for migration through completion of a migration assessment and then to provide adequate controls if the LFG management system is not sufficiently protective of on or off-site migration issues. Field activities for migration assessments typically include the installation of gas probes along the perimeter of the landfill. Perimeter gas probes are used to monitor LFG migration beyond the waste discharge area typically at or near the property line or nearby structures.

These perimeter probes mentioned in Table 7 are usually permanent installations for ongoing monitoring. Field activities for migration assessments typically include the installation of gas probes along the perimeter of the landfill. Perimeter gas probes are used to monitor LFG migration beyond the waste discharge area typically at or near the property line or nearby structures. These perimeter probes are usually permanent installations for ongoing monitoring. An LFG 
Table 7. Dangerous gas percentage and actions to prevent consequences.

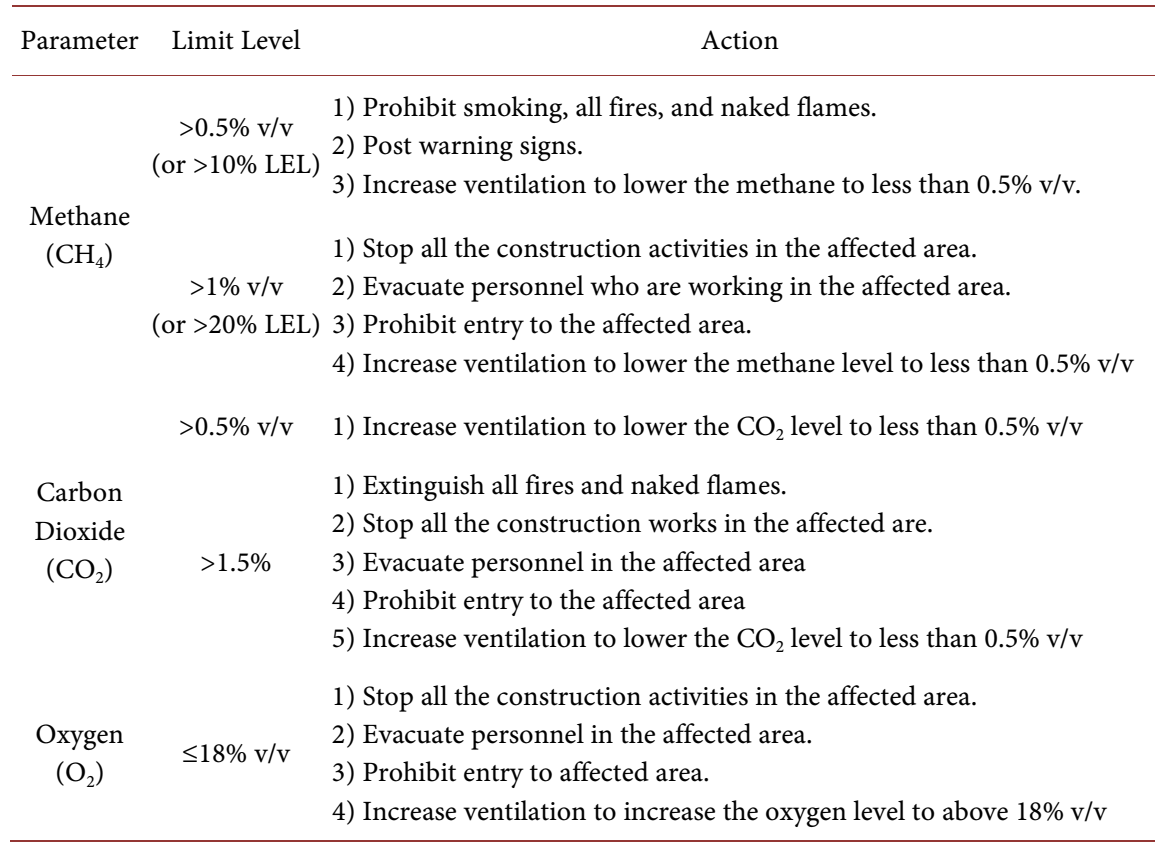

migration assessment should be completed by a Qualified Professional to identify potential risk and pathways of the LFG prior to installation of any monitoring probes. The perimeter gas probes should be monitored for combustible gas content and probe gauge pressure on a regular basis. Water levels within probes installed near the water table or in areas of perched water tables should be monitored to determine seasonal fluctuations in the water table at each location. It is expected that correctly installed gas probes should generally remain dry, but a varying water table surrounding the site may cause periodic flooding of some probes. Interpretation of soil gas data from flooded probes must be undertaken with great care, as LFG composition data is generally meaningless if the soil probe screen does not have access to soil gas. Immediately following each monitoring event, the data collected should be reviewed. The objectives of the review are:

- Verify unusual and/or erroneous readings,

- Identify problems and, if necessary, initiate remedial action (i.e., repair damaged,

- Probes, calibrate or repair equipment, etc.),

- Bring to the attention of the individuals responsible for detailed assessment and,

- Contingency plans, those readings that may indicate gas presence,

- Identify the occurrence of LFG migration,

- Develop any remedial actions that are warranted,

- Assess the effectiveness of any actions that may have been taken.

A more detailed evaluation of the data should be performed on an annual basis and should include an analysis of all prior readings for trends. This analysis is 
an important tool in anticipating the occurrence of migration and assessing the effectiveness of any remedial measures taken. Where an active LFG management system is present in the landfill, the performance of this system should be evaluated against monitoring data related to probe data. Optimization of the LFG management system may be required to address ongoing migration concerns. Note that analysis of monitoring data from perimeter probes is complex and must consider not only the monitoring results but also must take into account the following:

- Barometric pressure (may be incorporated into routine LFG collection field

- monitoring and/or tracked daily),

- Frost conditions,

- Soil stratigraphy,

- Hydrogeology,

- Status of LFG controls (if applicable).

The detection of combustible gas in the soil constitutes evidence of migration; the confluence of combustible gas with high-pressure readings indicates a situation where this combustible gas is migrating with a driving force beyond that of simple diffusion. Gauge pressures that are consistently positive in probes where combustible gas is detected give an indication of the magnitude of the force behind the migration. Gradients of combustible gas concentrations may be helpful in indicating the extent, range, and direction of migration. However, interpretation of concentration gradients may be complicated by physical and/or chemical processes acting upon the gases as they move through the soil. As indicated previously in this Guideline, such processes may have a preferential effect on some LFG constituents over others; specifically, the carbon dioxide component of LFG may be stripped into soil water over extended migration lengths, resulting in a proportionately-higher concentration of methane per unit volume. Soil gas concentrations at the property boundary should not exceed the lower explosive limit of methane ( 5 percent by volume). If greater than 5 percent by volume of methane is measured at the property boundary, an additional assessment must be conducted as soon as possible to assess the potential issues that may arise from LFG migration. Additional monitoring of the probes may be warranted, as well as residential monitoring if LFG migration is suspected in residential areas around the landfill.

The measurements of LFG migration are executed one per month and the following table shows the analysis of the measurements and the necessary actions that need to take place.

\subsection{Measurement Process and Results}

As it was mentioned before, the LFG measurements reveal to us whether the project is efficient or not. The contractor has given to us, the engineers, certain forms that we have to fill during the measurements. These forms are in excel format after they are filled with the collected data they are sent to the project 
manager in order to be analyzed that will reveal what the future actions for the project will be. The forms are seven and are completed for each cell. The measurements for each cell indicate whether there is an issue with the wells and the manifolds. The accepted measurements for methane and oxygen percentages have been mentioned Table 5 and Table 6 . In case the measurements reveal a problem with the wells/manifolds the engineers will proceed to solve the problem using certain techniques.

Below is a sample of each form (Appendix).

\section{Conclusions}

Waste to energy facilities has been increasing in number throughout the world as a solution to the problems societies have trying to manage enormous amounts of waste in the most environmentally friendly way possible. Although landfills are not the most effective and environmentally friendly method of waste treatment, many landfills exist around the world. These existing landfills give us the opportunity to take advantage of huge amounts of methane gas with high energy potential. The energy utilization of the landfill gas is crucial for the environment and for the society and as a result, the contractors try to ensure that the efficiency of the project is the highest possible. This can be achieved through many techniques that target to minimize the existence of leachate. These techniques have various benefits to landfill operations including an increased rate of refuse decomposition and landfill stabilization, reduction of leachate strength and associated leachate treatment cost, as well as increased methane gas production. Maximizing the production of biogas, we increase the potential energy that can be produced to provide the community with electricity and other forms of energy that improve the well-being of the people. In a world that the population keeps increasing along with the energy demands, finding new energy sources that serve the needs of the people and are also environmentally friendly, is something crucial.

It is certain that the more popular the method of producing energy from landfill gas gets, more research will be conducted on the subject and waste to energy projects will become even more efficient.

\section{Acknowledgements}

I would like to thank the contractor for giving me an opportunity to gain valuable experience working as an engineer while I just finished my freshman year at college. Special thanks to the project manager of the project Mr. Christodoulos Hadjidimoulas, the plan manager Mr. Zisis Papistas and the site engineers Mr. Odai Al Krimyin and Mr. Edward Qassar for the valuable help they offered me during my internship by teaching me about all matter of the project. Also, I want to thank the personnel of the Owner of the project Greater Amman Municipality (GAM) for their astonishing hospitality during this period and especially GAM's Manager Mr. Zaidoun Nsour and GAM's on-site Engineer Mr. Nessar Al Kouz. 


\section{Conflicts of Interest}

The authors declare no conflicts of interest regarding the publication of this paper.

\section{References}

[1] Detailed Design of the Project. Design, Built and Operate a Solid Waste Disposal Facility: A Landfill Gas Recovery and a Power Generation System at the Existing Ghabawi Landfill, Amman, Jordan. By J/V Constantinidis Helector Design Team.

[2] Personal Notes by Project Manager Mr. Christodoulos Hadjidimoulas, Mechanical Engineer.

[3] “Landfill Design-Guidelines-BC2010.pdf.” Accessed January 9, 2018.

http://www.build-a-biogas-plant.com/PDF/LandfillDesign-guidelines-BC2010.pdf

[4] Tchobanoglous, G., Theisen, H. and Vigil, S. Integrated Solid Waste Management. 


\section{Appendix}

Form 1. Daily report of boosting and flaring system.

\begin{tabular}{|c|c|c|c|c|c|c|c|}
\hline Day & Time & Blower & $\mathrm{CH}_{4}(\%)$ & $\mathrm{O}_{2}(\%)$ & $\begin{array}{l}\text { Wells in } \\
\text { Operation }\end{array}$ & $\begin{array}{l}\text { Suction } \\
\text { (-mbar) }\end{array}$ & $\begin{array}{c}\text { Flow } \\
\left(\mathrm{m}^{3} / \mathrm{hr}\right)\end{array}$ \\
\hline $1 / 6$ & 7:00 & 2 & 56 & 0.5 & 492 & 10 & 1341 \\
\hline $2 / 6$ & 7:00 & 2 & 55 & 0.6 & 492 & 15 & 1557 \\
\hline $3 / 6$ & 9:10 & 2 & 58 & 0.3 & 492 & 11 & 1548 \\
\hline $4 / 6$ & 7:00 & 2 & 55 & 0.6 & 492 & 13 & 1569 \\
\hline $5 / 6$ & 7:00 & 2 & 55 & 0.6 & 492 & 13 & 1558 \\
\hline $6 / 6$ & 7:00 & 2 & 55 & 0.6 & 492 & 13 & 1554 \\
\hline $7 / 6$ & $10: 00$ & 2 & 58 & 0.4 & 492 & 11 & 1534 \\
\hline $8 / 6$ & 7:00 & 2 & 55 & 0.6 & 492 & 13 & 1505 \\
\hline $9 / 6$ & 7:00 & 2 & 55 & 0.6 & 492 & 13 & 1519 \\
\hline $10 / 6$ & 7:00 & 2 & 55 & 0.6 & 492 & 13 & 1497 \\
\hline $11 / 6$ & 7:00 & 2 & 55 & 0.5 & 492 & 13 & 1503 \\
\hline $12 / 6$ & $7: 30$ & 2 & 55 & 0.6 & 492 & 14 & 1523 \\
\hline $13 / 6$ & 7:00 & 2 & 55 & 0.5 & 492 & 14 & 1503 \\
\hline $14 / 6$ & $7: 30$ & 2 & 55 & 0.6 & 492 & 14 & 1523 \\
\hline $15 / 6$ & 9:00 & 2 & 55 & 0.6 & 492 & 13 & 1516 \\
\hline $16 / 6$ & $7: 30$ & 2 & 55 & 0.6 & 492 & 14 & 1528 \\
\hline $17 / 6$ & 8:00 & 2 & 55 & 0.6 & 492 & 13 & 1559 \\
\hline $18 / 6$ & 7:00 & 2 & 55 & 0.7 & 492 & 13 & 1511 \\
\hline $19 / 6$ & $7: 30$ & 2 & 55 & 0.7 & 492 & 13 & 1508 \\
\hline $20 / 6$ & $7: 30$ & 2 & 54 & 0.7 & 492 & 13 & 1521 \\
\hline $21 / 6$ & $7: 30$ & 2 & 54 & 0.7 & 492 & 13 & 1520 \\
\hline $22 / 6$ & $8: 30$ & 2 & 54 & 0.7 & 492 & 14 & 1546 \\
\hline $23 / 6$ & 7:00 & 2 & 55 & 0.6 & 492 & 13 & 1566 \\
\hline $24 / 6$ & $7: 30$ & 2 & 54 & 0.7 & 492 & 14 & 1547 \\
\hline $25 / 6$ & 7:00 & 2 & 54 & 0.7 & 492 & 14 & 1546 \\
\hline $26 / 6$ & 7:00 & 2 & 54 & 0.7 & 492 & 13 & 1533 \\
\hline $27 / 6$ & 7:00 & 2 & 54 & 0.7 & 492 & 13 & 1546 \\
\hline $28 / 6$ & 7:00 & 2 & 54 & 0.7 & 492 & 14 & 1531 \\
\hline $29 / 6$ & 7:00 & 2 & 54 & 0.7 & 492 & 14 & 1550 \\
\hline $30 / 6$ & 7:00 & 2 & 54 & 0.7 & 492 & 14 & 1624 \\
\hline
\end{tabular}


Form 2. All cells manifold collector gas report.

\begin{tabular}{|c|c|c|c|c|c|}
\hline \multirow{2}{*}{ MANIFOLD } & \multicolumn{2}{|c|}{ DATE: $12 / 6 / 2017$} & \multirow{2}{*}{$\begin{array}{l}\text { SUCTION } \\
(-\mathrm{mbar})\end{array}$} & \multirow{2}{*}{$\begin{array}{c}\text { WELLS IN } \\
\text { OPERATION }\end{array}$} & \multirow{2}{*}{$\begin{array}{l}\text { TOTAL } \\
\text { WELLS }\end{array}$} \\
\hline & $\mathrm{CH}_{4}(\%)$ & $\mathrm{O}_{2}(\%)$ & & & \\
\hline \multicolumn{6}{|c|}{ CELL 1} \\
\hline PH2M1 & 47.6 & 0.9 & -4.2 & 15 & 16 \\
\hline PH2M2 & 54.9 & 0.7 & -4.9 & 16 & 16 \\
\hline PH2M3 & 48.7 & 1.6 & -5.1 & 16 & 16 \\
\hline $\mathrm{PH} 2 \mathrm{M} 4$ & 55.0 & 0.2 & -5.5 & 11 & 11 \\
\hline PH2M5 & 55.0 & 0.4 & -5.4 & 15 & 16 \\
\hline PH2M6 & 45.6 & 1.8 & -5.5 & 10 & 14 \\
\hline PH2M7 & 55.6 & 0.4 & -5.4 & 16 & 16 \\
\hline PH2M8 & 49.2 & 1.6 & -5.2 & 12 & 12 \\
\hline PH2M9 & 54.1 & 0.3 & -5.3 & 12 & 12 \\
\hline PH2M10 & 54.5 & 0.5 & -5.5 & 16 & 16 \\
\hline PH2M11 & 52.9 & 0.9 & -5.6 & 11 & 16 \\
\hline PH2M12 & 53.4 & 0.8 & -5.3 & 14 & 14 \\
\hline PH2M13 & 54.8 & 0.3 & -5.3 & 13 & 13 \\
\hline \multicolumn{6}{|c|}{ CELL 2} \\
\hline PH1M1 & 54.2 & 0.5 & -4.6 & 12 & 17 \\
\hline PH1M2 & 57.5 & 0.2 & -4.7 & 15 & 16 \\
\hline PH1M3 & 53.4 & 0.7 & -4.6 & 11 & 14 \\
\hline PH1M4 & 55.1 & 0.3 & -4.7 & 13 & 14 \\
\hline PH1M5 & 55.2 & 0.4 & -4.7 & 15 & 16 \\
\hline PH1M6 & 55.1 & 0.4 & -4.7 & 12 & 17 \\
\hline PH1M7 & 55.5 & 0.5 & -4.5 & 15 & 18 \\
\hline PH1M8 & 58.2 & 0.3 & -4.8 & 9 & 10 \\
\hline PH1M9 & 54.1 & 0.9 & -4.6 & 12 & 14 \\
\hline PH1M10 & 61.2 & 0.0 & -5.1 & 13 & 15 \\
\hline PH1M11 & 58.9 & 0.0 & -4.7 & 3 & 12 \\
\hline \multicolumn{6}{|c|}{ CELL 3} \\
\hline PH3M1 & 53.6 & 0.5 & -4.2 & 13 & 13 \\
\hline PH3M2 & 55.3 & 0.1 & -4.0 & 9 & 9 \\
\hline PH3M3 & 54.7 & 0.2 & -4.3 & 9 & 9 \\
\hline PH3M4 & 52.5 & 1.4 & -4.3 & 11 & 14 \\
\hline PH3M5 & 53.4 & 0.2 & -4.7 & 11 & 12 \\
\hline PH3M6 & 56.1 & 0.8 & -4.4 & 16 & 16 \\
\hline PH3M7 & 55.1 & 0.6 & -4.6 & 8 & 9 \\
\hline PH3M8 & 55.6 & 0.5 & -4.5 & 9 & 9 \\
\hline PH3M9 & 55.4 & 0.5 & -4.0 & 16 & 16 \\
\hline PH3M10 & 54.6 & 0.8 & -4.6 & 13 & 14 \\
\hline PH3M11 & 55.6 & 0.4 & -4.5 & 15 & 15 \\
\hline PH3M12 & 55.8 & 0.2 & -4.4 & 12 & 13 \\
\hline PH3M13 & 55.1 & 0.4 & -4.5 & 14 & 14 \\
\hline PH3M14 & 54.2 & 0.8 & -4.4 & 17 & 17 \\
\hline PH3M17 & 53.4 & 0.7 & -4.6 & 12 & 12 \\
\hline TOTAL & & & & 492 & 543 \\
\hline
\end{tabular}


Form 3. Cell 1: Manifold lines gas report.

\begin{tabular}{|c|c|c|c|c|c|}
\hline \multicolumn{6}{|c|}{ MANIFOLD: M 12} \\
\hline \multicolumn{6}{|c|}{ DATE: $21 / 6 / 2017$} \\
\hline WELL & $\mathrm{CH}_{4} \%(\mathrm{MAN})$ & $\mathrm{O}_{2} \%$ (MAN) & DP & FLOW & COMMENTS \\
\hline 168 & 53.2 & 0.3 & 0.1 & 2.5 & \\
\hline 157 & 54.8 & 0.0 & 1.9 & 11.0 & \\
\hline 169 & 54.5 & 0.0 & 0.2 & 3.6 & \\
\hline 182 & 54.6 & 0.0 & 0.2 & 3.6 & \\
\hline 170 & 54.5 & 0.0 & 0.1 & 2.5 & \\
\hline 183 & 54.3 & 0.9 & 0.1 & 2.5 & \\
\hline 158 & 55.1 & 0.0 & 1.1 & 8.4 & \\
\hline 171 & 53.1 & 0.3 & 0.1 & 2.5 & \\
\hline 184 & 50.6 & 1.1 & 0.3 & 4.4 & \\
\hline 172 & 54.8 & 0.4 & 0.2 & 3.6 & \\
\hline 159 & 54.6 & 0.0 & 1.9 & 11.0 & \\
\hline 160 & 46.4 & 2.8 & 4.4 & 16.8 & High $\mathrm{O}_{2}$ to be checked \\
\hline 147 & 52.8 & 0.8 & 0.9 & 7.6 & \\
\hline 146 & 47.8 & 2.7 & 4.2 & 16.4 & High $\mathrm{O}_{2}$ to be checked \\
\hline TOTAL & 53.4 & 0.8 & -9.9 & 96.4 & \\
\hline
\end{tabular}

SUMMARISED TABLE CELL 1

\begin{tabular}{ccccccc}
\hline MANIFOLD & $\mathrm{CH}_{4}$ & $\mathrm{O}_{2}$ & SUCTION & TOTAL & OPERATION & FLOW \\
\hline M1 & 47.6 & 0.9 & -6.4 & 16 & 15 & 121.50 \\
M2 & 54.9 & 0.7 & -9.1 & 16 & 16 & 133.32 \\
M3 & 48.7 & 1.6 & -9.3 & 16 & 16 & 91.48 \\
M4 & 55.0 & 0.2 & -9.1 & 11 & 11 & 50.10 \\
M5 & 55.0 & 0.4 & -9.8 & 16 & 15 & 77.74 \\
M6 & 45.6 & 1.8 & -6.7 & 14 & 10 & 62.61 \\
M7 & 55.6 & 0.4 & -9.6 & 16 & 16 & 162.15 \\
M8 & 49.2 & 1.6 & -9.9 & 12 & 12 & 89.49 \\
M9 & 54.1 & 0.3 & -9.9 & 12 & 12 & 57.14 \\
M10 & 54.5 & 0.5 & -9.8 & 16 & 16 & 56.70 \\
M11 & 52.9 & 0.9 & -9.9 & 16 & 11 & 50.78 \\
M12 & 53.4 & 0.8 & -9.9 & 14 & 14 & 96.44 \\
M13 & 54.8 & 0.3 & -9.9 & 13 & 13 & 43.56 \\
TOTAL & & & & 188 & 177 & 1093.02 \\
\hline
\end{tabular}


Form 4. Cell 2: Manifold lines and wells gas report.

\begin{tabular}{|c|c|c|c|c|c|c|c|c|c|}
\hline \multicolumn{10}{|c|}{ MANIFOLD: M 3} \\
\hline \multicolumn{10}{|c|}{ DATE: $14 / 6 / 2017$} \\
\hline Well & $\begin{array}{l}\mathrm{Ch}_{4} \% \\
\text { (man) }\end{array}$ & $\begin{array}{l}\mathrm{O}_{2} \% \\
\text { (man) }\end{array}$ & $\begin{array}{l}\mathrm{Ch}_{4} \% \\
\text { (well) }\end{array}$ & $\begin{array}{l}\mathrm{O}_{2} \% \\
\text { (well) }\end{array}$ & $\begin{array}{l}\text { Suction } \\
\text { (man) }\end{array}$ & $\begin{array}{l}\text { Suction } \\
\text { (well) }\end{array}$ & $\mathrm{Dp}$ & $\begin{array}{l}\text { Flow } \\
\left(\mathrm{m}^{3} / \mathrm{hr}\right)\end{array}$ & Comments \\
\hline 55 & 58.1 & 0.0 & 61.7 & 0.0 & -19.3 & -1.0 & 0.2 & 3.6 & \\
\hline 47 & 55.8 & 0.4 & 64.0 & 0.0 & -19.5 & -2.0 & 0.3 & 4.4 & \\
\hline 46 & 58.7 & 0.5 & 58.8 & 0.0 & -19.5 & -0.5 & 0.1 & 2.5 & \\
\hline 38 & 56.7 & 0.5 & 57.7 & 0.0 & -19.1 & -6.0 & 0.1 & 2.5 & \\
\hline 37 & 61.1 & 0.0 & 61.7 & 0.0 & -19.4 & -4.0 & 0.2 & 3.6 & \\
\hline 36 & 56.6 & 0.3 & 57.8 & 0.0 & -10.2 & -3.4 & 9.7 & 24.9 & \\
\hline 35 & 56.9 & 0.3 & 55.1 & 0.4 & -1.5 & 0.0 & 18.9 & 34.8 & $\begin{array}{l}\text { A lot of leachate. } \\
\text { To be pumped }\end{array}$ \\
\hline 45 & 46.1 & 1.5 & 51.4 & 0.8 & -19.6 & -18.6 & 0.2 & 3.6 & \\
\hline 34 & 49.7 & 1.1 & 52.0 & 0.7 & -19.7 & -16.0 & 0.1 & 2.5 & \\
\hline 23 & 60.8 & 0.5 & 59.5 & 0.3 & -19.2 & -18.7 & 0.2 & 3.6 & \\
\hline 44 & 56.7 & 0.0 & 56.2 & 0.0 & -6.6 & positive & 0.0 & 0.0 & $\begin{array}{c}\text { No flow. Blow } \\
\text { horizontal network }\end{array}$ \\
\hline 33 & 32.6 & 7.5 & 53.8 & 0.0 & -18.8 & positive & 0.0 & 0.0 & $\begin{array}{l}\text { Damaged pipe. } \\
\text { To be repaired }\end{array}$ \\
\hline 43 & 60.5 & 0.0 & 63.9 & 0.0 & -18.8 & 0.0 & 0.0 & 0.0 & $\begin{array}{l}\text { A lot of leachate. } \\
\text { To be pumped }\end{array}$ \\
\hline 54 & 60.7 & 0.0 & 60.0 & 0.0 & -18.7 & -16.6 & 0.1 & 2.5 & \\
\hline TOTAL & 53.4 & 0.7 & & & -11.0 & & & 88.5 & \\
\hline
\end{tabular}

\begin{tabular}{|c|c|c|c|c|c|c|}
\hline \multicolumn{7}{|c|}{ SUMMARIZED TABLE } \\
\hline \multirow{2}{*}{ Manifold } & \multirow{2}{*}{$\mathrm{Ch}_{4}$} & \multirow{2}{*}{$\mathrm{O}_{2}$} & \multirow{2}{*}{ Suction } & \multicolumn{2}{|c|}{ Wells } & \multirow{2}{*}{ Flow } \\
\hline & & & & Total & Operation & \\
\hline M1 & 54.2 & 0.5 & -11.1 & 16 & 12 & 101.38 \\
\hline M2 & 57.5 & 0.2 & -11.9 & 16 & 15 & 68.21 \\
\hline M3 & 53.4 & 0.7 & -11.0 & 14 & 11 & 88.51 \\
\hline M4 & 55.1 & 0.3 & -10.5 & 14 & 13 & 128.63 \\
\hline M5 & 55.2 & 0.4 & -8.1 & 17 & 15 & 98.51 \\
\hline M6 & 55.1 & 0.4 & -7.9 & 13 & 12 & 142.82 \\
\hline M7 & 55.5 & 0.5 & -10.7 & 17 & 15 & 219.45 \\
\hline M8 & 58.2 & 0.3 & -9.3 & 9 & 9 & 29.99 \\
\hline M9 & 54.1 & 0.9 & -10.7 & 14 & 12 & 67.20 \\
\hline M10 & 61.2 & 0.0 & -17.0 & 15 & 13 & 63.53 \\
\hline M11 & 58.9 & 0.0 & -11.3 & 12 & 3 & 15.10 \\
\hline TOTAL & & & & 157 & 130 & 1023.32 \\
\hline
\end{tabular}


Form 5. Cell 2: Leachate level measurements into lfg wells (measures from ground).

\begin{tabular}{|c|c|c|c|c|c|}
\hline \multicolumn{6}{|c|}{ DATE: MARCH 2017} \\
\hline Well & Final well depth & Leachate level (m) & Well (w) & Final well depth & Leachate level (m) \\
\hline 1 & 15.10 & 5 & 81 & 29.90 & 11.0 \\
\hline 2 & 13.90 & full leachate & 82 & 30.10 & 11.0 \\
\hline 3 & 13.90 & full leachate & 83 & 30.10 & 12.0 \\
\hline $3 \mathrm{~A}$ & & 6 & 84 & 30.10 & 11.0 \\
\hline 4 & 15.20 & 2 & 85 & 30.10 & 10.0 \\
\hline 5 & 17.10 & full leachate & 86 & 30.10 & 4.0 \\
\hline 6 & 18.00 & 5 & $86 \mathrm{~A}$ & 30.00 & 14.0 \\
\hline 7 & 18.00 & full leachate & 87 & 30.10 & 13.0 \\
\hline 8 & 18.00 & 5(MUD) & 88 & 30.10 & 13.0 \\
\hline 9 & 17.50 & 6 & 89 & 30.10 & 9.0 \\
\hline 10 & 16.30 & 6 & 90 & 29.90 & 13.0 \\
\hline 11 & 16.30 & full leachate & 91 & 29.90 & 12.0 \\
\hline 12 & 17.00 & 4 & 92 & 29.80 & 12.0 \\
\hline 13 & 21.40 & 4 & 93 & 29.90 & 6.0 \\
\hline $13 \mathrm{~A}$ & 21.00 & 5 & $93 \mathrm{~A}$ & 30.00 & 11.0 \\
\hline 14 & 20.60 & 7 & 94 & 30.10 & 11.0 \\
\hline 15 & 20.70 & 3 & 95 & 30.10 & 11.0 \\
\hline 16 & 21.60 & 6 & 96 & 30.10 & 11.0 \\
\hline 17 & 23.60 & 9 & 97 & 30.00 & 13.0 \\
\hline 18 & 24.20 & 9 & 98 & 29.90 & 7.0 \\
\hline 19 & 24.00 & 9 & $98 \mathrm{~A}$ & 30.00 & 15.0 \\
\hline 20 & 23.80 & 7 & 99 & 29.80 & 13.0 \\
\hline 21 & 22.60 & 3 & 100 & 29.80 & 13.0 \\
\hline 22 & 22.70 & 3 & 101 & 30.00 & 11.0 \\
\hline 23 & 28.00 & 12 & 102 & 29.00 & 11.0 \\
\hline 24 & 26.80 & 12 & 103 & 30.00 & 11.0 \\
\hline 25 & 26.30 & 12 & 104 & 29.90 & 11.0 \\
\hline 26 & 26.30 & 12 & 105 & 29.80 & 11.0 \\
\hline $26 \mathrm{~A}$ & 26.00 & 12 & 106 & 29.90 & 11.0 \\
\hline 27 & 27.70 & 13 & 106 & 29.80 & 11.0 \\
\hline 28 & 29.30 & 14 & 107 & 30.10 & 12.0 \\
\hline 29 & 29.20 & 14 & 108 & 30.00 & 11.0 \\
\hline 30 & 29.30 & 14 & 109 & 29.70 & 13.0 \\
\hline 31 & 28.90 & 14 & 110 & 29.00 & 14.0 \\
\hline 32 & 29.30 & 14 & 111 & 23.70 & full leachate \\
\hline
\end{tabular}




\section{Continued}

\begin{tabular}{|c|c|c|c|c|c|}
\hline 33 & 27.00 & 3 & 112 & 28.00 & 8.0 \\
\hline $33 \mathrm{~A}$ & 27.00 & 7 & 113 & 27.90 & 8.0 \\
\hline 34 & 27.80 & 12 & 114 & 27.30 & 9.0 \\
\hline 35 & 29.50 & 13 & 115 & 28.70 & 9.0 \\
\hline 36 & 29.40 & 5 & 116 & 29.00 & 9.0 \\
\hline $36 \mathrm{~A}$ & 30.00 & 14 & 117 & 29.30 & 9.0 \\
\hline 37 & 29.20 & 14 & 118 & 30.00 & 10.0 \\
\hline 38 & 29.30 & 12 & 119 & 29.10 & 11.0 \\
\hline 39 & 29.50 & 12 & 120 & 29.90 & 10.0 \\
\hline 40 & 27.50 & 10 & 121 & 29.10 & 11.0 \\
\hline 41 & 29.20 & 13 & 122 & 23.20 & full leachate \\
\hline 42 & 29.30 & 12 & 123 & 22.80 & full leachate \\
\hline 43 & 29.50 & 2 & 124 & 22.30 & full leachate \\
\hline 44 & 29.20 & 5 & 125 & 22.30 & full leachate \\
\hline $44 \mathrm{~A}$ & 29.00 & 13 & 126 & 25.20 & full leachate \\
\hline 45 & 26.90 & 9 & 127 & 26.40 & full leachate \\
\hline 46 & 29.70 & 9 & 128 & 27.00 & full leachate \\
\hline 47 & 29.60 & 9 & 129 & 27.50 & full leachate \\
\hline 48 & 29.70 & 9 & 130 & 27.00 & 3.0 \\
\hline 49 & 29.40 & 9 & $130 \mathrm{~A}$ & 27.00 & 9.0 \\
\hline 50 & 30.00 & 9 & 131 & 26.80 & 7.0 \\
\hline 51 & 29.80 & 10 & 132 & 25.50 & 4.0 \\
\hline 52 & 30.00 & 16 & 133 & 13.10 & full leachate \\
\hline 53 & 30.10 & 2 & 134 & 17.70 & full leachate \\
\hline 54 & 22.50 & 5 & 135 & 16.50 & 3.0 \\
\hline 55 & 30.10 & 12 & 136 & 17.90 & full leachate \\
\hline 56 & 30.20 & 6 & 137 & 19.00 & full leachate \\
\hline $56 \mathrm{~A}$ & 30.00 & 14 & 138 & 20.20 & full leachate \\
\hline 57 & 30.10 & 6 & 139 & 21.00 & full leachate \\
\hline 58 & 30.00 & 5 & 140 & 21.70 & full leachate \\
\hline $58 \mathrm{~A}$ & 30.00 & 13 & 141 & 21.40 & 6.0 \\
\hline 59 & 30.10 & 10 & 142 & 21.10 & 6.0 \\
\hline 60 & 30.10 & 10 & 143 & 20.50 & 6.0 \\
\hline 61 & 29.60 & 10 & 144 & 19.00 & full leachate \\
\hline 62 & 30.10 & 10 & 145 & 14.50 & full leachate \\
\hline 63 & 30.10 & 4 & 146 & 12.80 & full leachate \\
\hline $63 \mathrm{~A}$ & 30.00 & 13 & 147 & 12.40 & full leachate \\
\hline
\end{tabular}




\section{Continued}

\begin{tabular}{|c|c|c|c|c|c|}
\hline 64 & 30.00 & 13 & 148 & 11.80 & full leachate \\
\hline 65 & 30.10 & 13 & 149 & 12.60 & full leachate \\
\hline 66 & 30.10 & 13 & 150 & 13.50 & full leachate \\
\hline 67 & 30.10 & 13 & 151 & 14.80 & full leachate \\
\hline 68 & 30.10 & 5 & 152 & 14.30 & borders $2 \& 4$ \\
\hline $68 \mathrm{~A}$ & 30.00 & 12 & 153 & 14.50 & borders $2 \& 4$ \\
\hline 69 & 30.10 & 9 & 154 & 15.00 & borders $2 \& 4$ \\
\hline 70 & 30.10 & 8 & 155 & 15.60 & borders $2 \& 4$ \\
\hline 71 & 29.40 & 8 & 156 & 16.00 & borders $2 \& 4$ \\
\hline 72 & 29.00 & 9 & & & \\
\hline 73 & 27.00 & 8 & & & \\
\hline 74 & 25.60 & 9 & & & \\
\hline 75 & 29.60 & 7 & & & \\
\hline 76 & 29.70 & 13 & & & \\
\hline 77 & 29.40 & 7 & & & \\
\hline $77 \mathrm{~A}$ & 29.00 & 15 & & & \\
\hline 78 & 29.50 & 5 & & & \\
\hline 79 & 30.00 & 5 & & & \\
\hline 80 & 29.90 & 5 & & & \\
\hline $80 \mathrm{~A}$ & 30.00 & 11 & & & \\
\hline
\end{tabular}

Form 6. Cell 2: Settlement markers coordinates.

\begin{tabular}{|c|c|c|c|c|c|c|}
\hline \multirow{2}{*}{ Cell 2} & \multirow{2}{*}{ Marker } & & \multirow{2}{*}{ Northing (y) } & \multirow{2}{*}{$\frac{\text { DECEMBER } 2016}{\text { Elevation }(\mathrm{z})}$} & \multirow{2}{*}{$\begin{array}{c}\text { MARCH } 2017 \\
\text { Elevation }(\mathrm{z})\end{array}$} & \multirow{2}{*}{$\begin{array}{l}\text { JUNE } 2017 \\
\text { Elevation }(\mathrm{z})\end{array}$} \\
\hline & & & & & & \\
\hline PH1M & 1 & $262,296.4919$ & $149,556.1337$ & 797.35 & 799.50 & 799.454 \\
\hline PH1M & 2 & $262,333.8712$ & $149,556.1347$ & 796.93 & 796.78 & 796.75 \\
\hline PH1M & 3 & $262,383.8534$ & $149,556.1328$ & 796.93 & 796.74 & 796.722 \\
\hline PH1M & 4 & $262,433.8627$ & $149,556.1319$ & 799.46 & 799.27 & 799.219 \\
\hline PH1M & 5 & $262,483.8767$ & $149,556.1337$ & 800.20 & 800.02 & 800.004 \\
\hline PH1M & 6 & $262,533.8718$ & $149,556.1397$ & 800.09 & 799.93 & 799.902 \\
\hline PH1M & 7 & $262,581.6487$ & $149,556.1346$ & 798.47 & 800.10 & 800.015 \\
\hline PH1M & 8 & $262,298.9330$ & $149,506.8580$ & 809.45 & 809.25 & 809.176 \\
\hline PH1M & 9 & $262,333.8620$ & $149,505.3370$ & 808.86 & 808.63 & 808.563 \\
\hline PH1M & 10 & $262,384.1490$ & $149,506.1240$ & 810.13 & 809.90 & 809.834 \\
\hline PH1M & 11 & $262,433.7740$ & $149,506.1890$ & 812.48 & 812.26 & 812.161 \\
\hline PH1M & 12 & $262,482.5820$ & $149,506.1930$ & 813.80 & 813.54 & 813.444 \\
\hline PH1M & 13 & $262,533.5350$ & $149,506.4400$ & 812.77 & 812.54 & 812.455 \\
\hline PH1M & 14 & $262,298.2400$ & $149,454.8810$ & 815.54 & 815.28 & 815.162 \\
\hline
\end{tabular}




\section{Continued}

\begin{tabular}{|c|c|c|c|c|c|c|}
\hline PH1M & 15 & $262,333.8380$ & $149,456.4190$ & 815.86 & 815.58 & 815.47 \\
\hline PH1M & 16 & $262,384.0470$ & $149,454.9830$ & 817.19 & 816.94 & 816.834 \\
\hline PH1M & 17 & $262,433.8700$ & $149,456.4430$ & 818.43 & 818.20 & 818.112 \\
\hline PH1M & 18 & $262,484.0200$ & $149,456.3170$ & 818.22 & 817.98 & 817.874 \\
\hline PH1M & 19 & $262,533.8770$ & $149,456.1621$ & 816.77 & 816.52 & 816.517, \\
\hline PH1M & 20 & $262,297.8220$ & $149,406.9580$ & 817.28 & 817.19 & 817.111 \\
\hline PH1M & 21 & $262,333.7800$ & $149,406.4090$ & 816.97 & 816.81 & 816.684 \\
\hline PH1M & 22 & $262,383.8450$ & $149,406.3490$ & 818.75 & 818.66 & 818.572 \\
\hline PH1M & 23 & $262,433.8810$ & $149,405.7540$ & 819.73 & 819.62 & 819.563 \\
\hline PH1M & 24 & $262,484.0470$ & $149,406.2910$ & 819.38 & 819.29 & 819.243 \\
\hline PH1M & 25 & $262,533.7670$ & $149,406.0870$ & 818.32 & 818.21 & 818.157 \\
\hline PH1M & 26 & $262,294.3660$ & $149,355.6820$ & 817.00 & 816.40 & 816.299 \\
\hline PH1M & 27 & $262,334.0770$ & $149,356.0550$ & 816.53 & 816.45 & 816.343 \\
\hline PH1M & 28 & $262,383.9060$ & $149,356.3680$ & 817.95 & 817.86 & 817.748 \\
\hline PH1M & 29 & $262,433.7780$ & $149,356.3260$ & 818.80 & 818.77 & 818.644 \\
\hline PH1M & 30 & $262,484.1810$ & $149,356.0420$ & 818.54 & 818.46 & 818.363 \\
\hline PH1M & 31 & $262,533.9570$ & $149,356.0050$ & 818.29 & 818.22 & 818.158 \\
\hline PH1M & 32 & $262,296.2570$ & $149,306.2000$ & 811.82 & 811.76 & 811.703 \\
\hline PH1M & 33 & $262,333.8170$ & $149,306.0580$ & 811.93 & 811.86 & 811.804 \\
\hline PH1M & 34 & $262,383.9240$ & $149,305.7380$ & 812.37 & 812.32 & 812.245 \\
\hline PH1M & 35 & $262,433.7510$ & $149,306.2580$ & 815.97 & 815.88 & 815.814 \\
\hline PH1M & 36 & $262,483.7650$ & $149,306.1010$ & 816.60 & 816.52 & 816.446 \\
\hline PH1M & 37 & $262,533.8490$ & $149,305.7790$ & 816.79 & 816.73 & 816.654 \\
\hline PH1M & 38 & $262,295.8080$ & $149,255.8590$ & 803.44 & 803.66 & 803.578 \\
\hline PH1M & 39 & $262,334.1190$ & $149,256.2070$ & 803.30 & 803.26 & 803.203 \\
\hline PH1M & 40 & $262,383.6720$ & $149,256.0760$ & 803.73 & 803.72 & 803.654 \\
\hline PH1M & 41 & $262,433.7010$ & $149,256.0670$ & 805.52 & 805.48 & 805.438 \\
\hline PH1M & 42 & $262,483.9150$ & $149,255.8330$ & 806.95 & 806.93 & 806.846 \\
\hline PH1M & 43 & $262,533.5050$ & $149,255.6670$ & 806.45 & 806.42 & REMOVED \\
\hline PH1M & 44 & $262,584.2240$ & $149,256.1500$ & 805.02 & BROKEN & REMOVED \\
\hline
\end{tabular}

